\title{
Pegylated liposomal doxorubicin in the management of ovarian cancer
}

This article was published in the following Dove Press journal:

Therapeutics and Clinical Risk Management

28 September 2010

Number of times this article has been viewed

\author{
Gabriella Ferrandina ${ }^{1,2}$ \\ Giacomo Corrado' \\ Angelo Licameli' \\ Domenica Lorusso ${ }^{2}$ \\ Gilda Fuoco' \\ Salvatore Pisconti ${ }^{3}$ \\ Giovanni Scambia ${ }^{2}$ \\ 'Gynecologic Oncology Unit, \\ Department of Oncology, Catholic \\ University of Campobasso, \\ Campobasso, Italy; ${ }^{2}$ Gynecologic \\ Oncology Unit, Catholic University \\ of Rome, Rome, Italy; ${ }^{3}$ Salvatore \\ Pisconti, Oncology Unit, Taranto \\ Hospital, Taranto, Italy
}

\begin{abstract}
Among the pharmaceutical options available for treatment of ovarian cancer, much attention has been progressively focused on pegylated liposomal doxorubicin (PLD), whose unique formulation, which entraps conventional doxorubicin in a bilayer lipidic sphere surrounded by a polyethylene glycol layer, prolongs the persistence of the drug in the circulation and potentiates intratumor drug accumulation. These properties enable this drug to sustain its very favorable toxicity profile and to be used safely in combination with other drugs. PLD has been already approved for treatment of advanced ovarian cancer patients failing first-line platinum-based treatment. Moreover, phase III trials have been already completed, and results are eagerly awaited, which hopefully will expand the range of PLD clinical application in this neoplasia both in front-line treatment, and in the salvage setting in combination with other drugs. Moreover, attempts are continuing to enable this drug to be combined with novel cytotoxic drugs and target-based agents. This review aims at summarizing the available evidence and the new perspectives for the clinical role of PLD in the management of patients with epithelial ovarian cancer.
\end{abstract}

Keywords: pegylated liposomal doxorubicin, ovarian cancer, clinical trials

\section{Introduction}

Epithelial ovarian carcinoma ( $\mathrm{OvCa})$ is one of the most common gynecological malignancies, and the fifth most frequent cause of cancer death in women. ${ }^{1}$ Worldwide, more than 190,000 new cases of ovarian cancer are diagnosed each year accounting for around 5\% of all cancers in women. In 2009, 21,550 new cases were estimated to have been diagnosed in the US. ${ }^{1}$

The standard of care for the management of OvCa patients includes surgery for staging and optimal cytoreduction (residual tumor $<1 \mathrm{~cm}$ ) followed by adjuvant chemotherapy with a platinum/taxane combination. ${ }^{2,3}$ However, despite the advances in surgical efforts and the achievement of high response rates to front-line treatment, OvCa remains the most lethal gynecological malignancy, almost $50 \%$ to $75 \%$ of cases experiencing progression/recurrence of disease, and a 5-year overall survival OS of $25 \%$ to $30 \%$ in advanced stage disease. ${ }^{1,3}$

The major determinants of clinical outcome are represented by the extent of residual tumor at primary surgery and sensitivity to platinum-based therapy, ${ }^{4}$ the latter generally being defined according to the duration of the platinum-free interval (PFI). In particular, patients are considered platinum resistant if progression/recurrence of disease occurs during chemotherapy or within 6 months from its completion; in this clinical setting, second-line single-agent chemotherapy with non-platinum drugs results 
in short-lived response rates of approximately $10 \%$ to $25 \%$, regardless of type of drugs used. ${ }^{5}$ On the other hand, patients defined as platinum sensitive, i.e. recurring/progressing after 6 months from the end of primary treatment, are usually treated with platinum-based combinations. ${ }^{4,5}$ Indeed, in the context of platinum sensitivity, relapse/progression within 6 to 12 months after the administration of primary chemotherapy represents a type of gray zone in terms of platinum resistance/responsiveness, and this is strongly supported by the clinical evidence in this subset of patients, the response rates range between $27 \%$ and $33 \%$ regardless of whether a platinum-based re-challenge or non-platinum drugs are used. ${ }^{6}$

In any case, besides the extent of response rates, other issues have to be taken into account in the choice of medical treatment, whether in front-line or second-line setting, including the rate and profile of side effects, especially for drug combinations and their impact on patients' quality of life. In this context, among the pharmaceutical options currently available for medical treatment of $\mathrm{OvCa}$, greater emphasis has been placed progressively on pegylated liposomal doxorubicin (PLD) (Doxil $^{\circledR}$ in the US; Caelyx ${ }^{\circledR}$ in Canada and Europe), which was approved in 1999 by the FDA and in 2000 by the European Medicines Evaluation Agency (EMEA) as single agent for treatment of advanced OvCa patients failing first-line platinum-based treatment. Moreover, phase III trials have been already conducted, and results from other studies are eagerly awaited, exploring the efficacy of PLD in salvage setting and in front-line treatment in combination with other therapeutic drugs.

This review will focus on the clinical role of PLD in the management of patients with epithelial OvCa. A brief summary of the process of PLD development, as well as new perspectives on PLD use, will also be provided.

\section{PLD: development, structure, and pharmacokinetic features}

PLD is a unique formulation of conventional doxorubicin in which the drug is encapsulated in a bilayer lipidic sphere $^{7}$ of approximately $100 \mathrm{~nm}$ (Figure 1): in contrast to other nanoparticles, the liposomal shell is surrounded by a polyethylene glycol (PEG) layer which represents a hydrophilic protective barrier between the liposome and the microenvironment, which prevents the interaction between circulating proteins and the lipidic bilayer: indeed, this phenomenon facilitates the activation of the reticulo endothelial system, thus leading to the destruction of the liposomal structure and release of the free drug. Therefore, the pegylation process plays a relevant role in prolonging the persistence of the drug in the circulation. It has also to be acknowledged that the size of PLD, while reducing or even preventing the extravasation of the drug in normal tissues, whose capillaries
A<smiles>COc1cccc2c1C(=O)c1c(O)c3c(c(O)c1C2=O)C[C@@](O)(C(=O)CO)C[C@H]3OC1CCC(N)C(O)C(C)O1</smiles>

C

$\mathrm{N}$-2,2-distearoyl-sn-glycerol-3-phosphoethanolamine sodium salt (MPEG-DSPE)

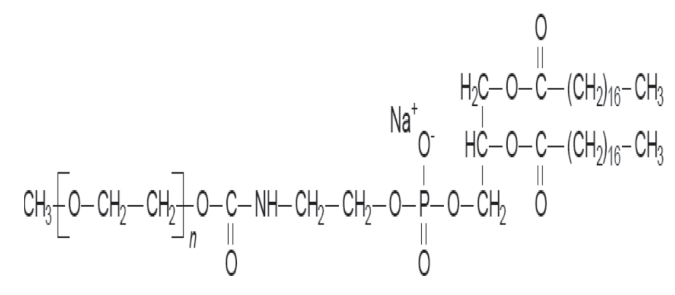

B Fully hydrogenated soy phosphatidylcholine (HSPC)

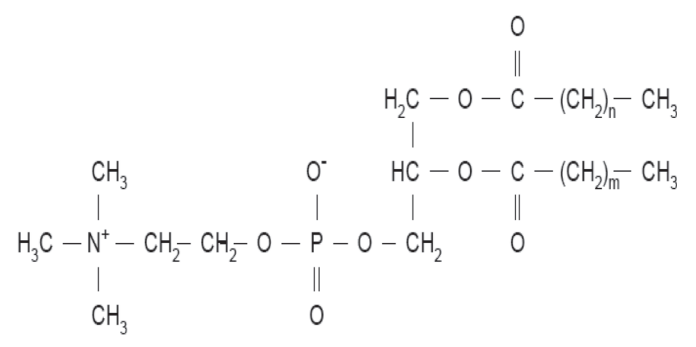

D

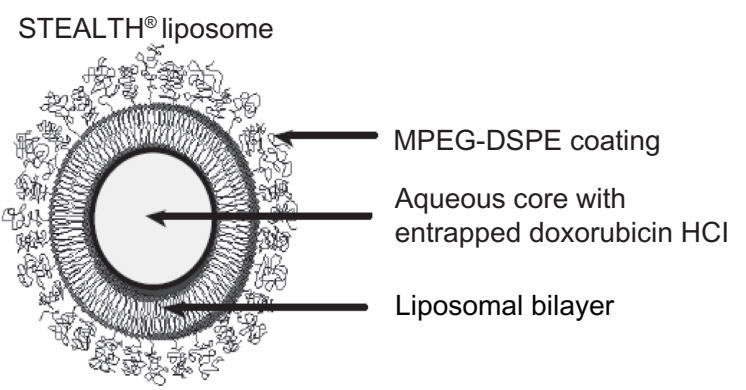

Figure I Structural form of doxorubicin HCL (A), fully hydrogenated soy phosphatidylcholine (B), and N-2,2-distearoyl-sn-glycerol-3-phosphoethanolamine sodium salt (MPEG-DSPE) (C), comprising the STEALTH ${ }^{\circledR}$ liposome structure (D). 
have a basal membrane and share very tight intercellular junctions, allows a facilitated uptake in tumor tissues which are characterized by loose capillary junctions. Finally, the absence of a structured lymphatic system in neoplastic tissues prevents PLD being cleared, and potentiates intratumor drug accumulation. These properties, which represent the rational basis for the exploitation of nanoparticle technology, sustain not only one of the major advantages of PLD, ie, lower cardiotoxicity and gastrointestinal toxicity compared to the free drug, but also its well-known pharmacokinetic features, such as long circulation time, minimal $(<5 \%)$ drug leakage from circulating liposomes, as well as half-lives of approximately 60 to 80 hours for doses in the range of 35 to $70 \mathrm{mg} / \mathrm{m}^{2}$ in patients with solid tumors, ${ }^{8,9}$ this would, in turn, translate, as reported by Gabizon et al, ${ }^{9}$ to a PLD AUC approximately 250 -fold higher than that of the free drug in humans. In particular, it has been shown that after PLD administration nearly $100 \%$ of the drug in the plasma is in the encapsulated form; moreover, compared to free doxorubicin, PLD plasma clearance is dramatically slower $(0.1 \mathrm{~L} / \mathrm{h}$ for PLD vs $45 \mathrm{~L} / \mathrm{h}$ for free doxorubicin), and its volume of distribution is very small (4 L vs $254 \mathrm{~L}$, respectively). ${ }^{9}$ The pharmacokinetics of PLD are still being investigated: there seems to be a complex interaction between pharmacokinetics and pharmacodynamics which could account for some patterns of toxicity; for instance, stomatitis/mucositis is documented more frequently at higher peak dose drug level, while cutaneous toxicity depends on dose interval or dose intensity, as shown by recent data showing that repeated PLD administrations result in cumulative inhibition of the clearance process. ${ }^{10}$

Advances in nanoparticle technology have fuelled great enthusiasm for the possibility of further enhancing the selective intratumor accumulation of PLD, and shifting the therapeutic index toward more tolerable toxicity profiles: in this context, the preliminary observations that recombinant serum albumine-conjugated PLD has longer blood circulating properties, smaller hepatic and splenic clearance, and more important, larger intratumor accumulation than PLD in preclinical models is very encouraging. ${ }^{11}$

\section{Phase I studies with PLD as single agent or in combination}

Table 1 summarizes the studies investigating the safety and assessing the maximum tolerated dose (MTD) of PLD used as a single agent: ${ }^{12-19}$ different dose escalation and schedules have been explored with PLD dose intensities, ranging from 10 to $15 \mathrm{mg} / \mathrm{m}^{2} /$ week. Stomatitis was reported as the most frequent dose limiting toxicity (DLT) at PLD doses $\geq 60 \mathrm{mg} / \mathrm{m}^{2}$, while at lower doses with schedules $<21$ days, the most common DLT was represented by hand-foot syndrome (HFS). Neutropenia was the DLT in two studies exploring dose-dense regimens, ${ }^{12,13}$ and in a series of 24 patients with pediatric solid tumors, treated with PLD doses of 40 to $50 \mathrm{mg} / \mathrm{m}^{2}$ every 28 days. ${ }^{19}$ The current PLD dosage as a single agent as indicated for ovarian cancer patients is $50 \mathrm{mg} / \mathrm{m}^{2}$ every 28 days.

Among the novel perspectives relative to PLD use, the investigation of escalating ( 15 to $100 \mathrm{mg} / \mathrm{m}^{2}$ ) doses of PLD plus hyperthermic intraperitoneal chemotherapy following optimal cytoreduction has been carried out in a phase I study including 21 advanced stage solid tumors including 3 patients with ovarian cancer. ${ }^{20}$ The most common grade $3 / 4$ toxicities were superficial wound infections $(n=6)$, and prolonged ileus $(\mathrm{n}=2)$. The most severe complication was represented by a post-operative anastomotic leakage requiring re-laparotomy.

Given the evidences of a different toxicity profile, PLD safety has been also investigated in combinations involving two or even three agents: ${ }^{21-64}$ in the dose-finding studies exploring combinations of PLD with cisplatin (CDDP) (Table 2), the DLTs were mostly represented by mucositis, and also neutropenia when CDDP was used at doses $>60 \mathrm{mg} / \mathrm{m}^{2}$ every 28 days. ${ }^{21,22}$ Similarly, when combining PLD with

Table I Phase I studies with pegylated liposomal doxorubicin as a single agent

\begin{tabular}{|c|c|c|c|c|c|}
\hline Author & No.pts & Type of tumor & MTD & DI mg/m²/week & DLTs \\
\hline Bogner $^{12}$ & 40 & Kaposi sarcomas & $20 \mathrm{mg} / \mathrm{m}^{2}, \mathrm{q} / 5$ & 10 & neutropenia \\
\hline James $^{13}$ & 15 & Kaposi sarcomas & $20 \mathrm{mg} / \mathrm{m}^{2}, \mathrm{q} / 5$ & 10 & hematologic \\
\hline Uziely $^{14}$ & 56 & Solid tumors & $60 \mathrm{mg} / \mathrm{m}^{2}, \mathrm{q} 28$ & 15 & $\begin{array}{l}\text { stomatitis (doses } \geq 60 \mathrm{mg} / \mathrm{m}^{2} \text { ) for } \\
\text { a single dose HFS (interval }<28 \mathrm{~d} \text { ) }\end{array}$ \\
\hline$J^{\prime a h a n z e b}{ }^{15}$ & 24 & Solid tumors & $40-50 \mathrm{mg} / \mathrm{m}^{2}, \mathrm{q} 28$ & $10-12.5$ & neutropenia \\
\hline Gabizon $^{16}$ & 22 & $\mathrm{MBC}$ & $50 \mathrm{mg} / \mathrm{m}^{2}, \mathrm{q} 28$ & 12.5 & $\begin{array}{l}\text { stomatitis (doses }>60 \mathrm{mg} / \mathrm{m}^{2} \text { ) } \\
\text { HFS (interval }<2 \text { l d) }\end{array}$ \\
\hline Caponigro ${ }^{17}$ & 24 & Head/neck & $45 \mathrm{mg} / \mathrm{m}^{2}, \mathrm{q} 2 \mathrm{l}$ & 15 & stomatitis \\
\hline Hamilton $^{18}$ & 20 & $\mathrm{MBC}$ & $60 \mathrm{mg} / \mathrm{m}^{2}, \mathrm{q} 42$ & 10 & mucositis \\
\hline Marina $^{19}$ & 22 & Pediatric solid tumors & $60 \mathrm{mg} / \mathrm{m}^{2}, \mathrm{q} 28$ & 15 & mucositis \\
\hline
\end{tabular}

Abbreviations: DI, dose intensity; DLT, dose limiting toxicity; HFS, hand-foot syndrome; MBC, metastatic breast cancer; MTD, maximum tolerated dose; q, every; d, day. 
carboplatin (JM8), DLTs consisting in stomatitis/mucositis were documented at PLD doses $>50 \mathrm{mg} / \mathrm{m}^{2}$, while thrombocytopenia was the most frequently reported DLT for lower PLD doses, with the exception of the study by Hamilton et al. ${ }^{25}$

The MTD of oxaliplatin (OXA) combined with fixed doses of PLD as salvage treatment of pre-treated advanced ovarian cancer was $130 \mathrm{mg} / \mathrm{m}^{2}$, as 2 out of 3 patients of this cohort showed dose-limiting thrombocytopenia and/or neutropenia during the first cycle of treatment. ${ }^{28}$

For the combination of PLD/taxanes ${ }^{29-46}$ (Table 3), the tolerability of PLD (at doses ranging from 30 to $40 \mathrm{mg} / \mathrm{m}^{2}$ ) combined with paclitaxel (PTX) (135 to $200 \mathrm{mg} / \mathrm{m}^{2}$ every 21 days) was acceptable; similarly, PLD at doses of 30 to $40 \mathrm{mg} / \mathrm{m}^{2}$, plus docetaxel (DTX) at doses of 67.5 to $80 \mathrm{mg} / \mathrm{m}^{2}$, was reported as the MTD for this combination. Based on the hypothesis that weekly administration could limit toxicity while keeping the dose intensity unchanged, weekly or bi-weekly administration of PLD (doses from 10 to $20 \mathrm{mg} / \mathrm{m}^{2}$ ) plus weekly PTX has been also explored. ${ }^{32,34-36}$

For weekly administration of PLD and DTX the MTDs corresponded to PLD $20 \mathrm{mg} / \mathrm{m}^{2}$ and DTX $25 \mathrm{mg} / \mathrm{m}^{2}$, every 28 days. ${ }^{43}$ The DLTs were mostly mucositis and neutropenia.

Given the peculiar not overlapping toxicity profile as well as the different mechanism of action of PLD compared to platinum agents and taxanes, it is not surprising that PLD tolerability has been also explored in combination with the most active regimen in ovarian cancer: ${ }^{47-49}$ the addition of
PLD to JM8/PTX led to defining the MTD as corresponding to JM8 AUC 6, and PTX $175 \mathrm{mg} / \mathrm{m}^{2}$ every 21 days, plus PLD $30 \mathrm{mg} / \mathrm{m}^{2}$ administered, as recommended, every other cycle. With this 3-drug regimen the same pattern of DLTs documented with the doublets was reported. Given the strong biological rationale of combining PLD, an inhibitor of topoisomerase II, with topoisomerase I inhibitors, as well as the non-overlapping toxicity profile of these two classes of drugs, the safety of PLD/topotecan (TPT) combination has been the subject of active investigation ${ }^{50-60}$ (Table 5). The MTD was reached at PLD doses of 30 and $40 \mathrm{mg} / \mathrm{m}^{2}$, every 21 or 28 days, and at TPT doses ( 0.5 to $1.0 \mathrm{mg} / \mathrm{m}^{2} /$ day $)$ administered with the classic shorter courses (days 1 to 3 or days 1 to 5 ). DLTs were represented in the vast majority of the studies by hematological toxicity. On the other hand, the use of longer courses (days 1 to 14 , days 1 to 21 ), or longer intervals (up to 5 weeks) seemed to be associated with a higher tolerability profile.

PLD safety has been investigated also in combination with other chemotherapeutics such as etoposide, vinorelbine, and gemcitabine, ${ }^{61-63}$ however, in spite of generally positive reports, only a few combinations have progressed to phase II evaluation (see below).

\section{Phase Il studies with PLD as single agent or in combination}

A summary of phase II studies using PLD as single agent in ovarian cancer is presented in Table $6 .{ }^{65-80}$

Table 2 Phase I studies with pegylated liposomal doxorubicin in combination with platinum agents

\begin{tabular}{|c|c|c|c|c|}
\hline Author & No.pts & Type of tumor & MTD & DLTs \\
\hline \multirow[t]{2}{*}{ Klein $^{21}$} & 25 & Solid tumors & CDDP $50 \mathrm{mg} / \mathrm{m}^{2}, \mathrm{~d} 8$ & mucositis \\
\hline & & & PLD $50-60 \mathrm{mg} / \mathrm{m}^{2}, \mathrm{dl}, \mathrm{q} 28$ & skin toxicity \\
\hline \multirow[t]{2}{*}{ Lyass $^{22}$} & 24 & Solid tumors & CDDP $60 \mathrm{mg} / \mathrm{m}^{2}$ & mucositis \\
\hline & & & PLD $50 \mathrm{mg} / \mathrm{m}^{2}, \mathrm{q} 28$ & neutropenia \\
\hline \multirow[t]{3}{*}{ Uys $^{23}$} & 19 & Solid tumors & JM8 AUC 5 & stomatitis \\
\hline & & & PLD 50 mg/m², q28 & neutropenia \\
\hline & & & & thrombocytopenia \\
\hline \multirow[t]{2}{*}{ Goncalves $^{24}$} & 22 & Solid tumors & JM8 AUC 5, q21,28 & neutropenia \\
\hline & & & PLD 35 mg/m² & thrombocytopenia \\
\hline \multirow[t]{2}{*}{ Hamilton ${ }^{25}$} & 20 & Solid tumors & JM8 AUC 6 & none \\
\hline & & & PLD 30 mg/m², q2I & \\
\hline Gonzalez- & 26 & Ovarian cancer & JM8 AUC 5 & mucositis \\
\hline Billalabeitia $^{26}$ & & & PLD $40 \mathrm{mg} / \mathrm{m}^{2}$, q28 & thrombocytopenia \\
\hline \multirow[t]{3}{*}{ du Bois ${ }^{27}$} & $36^{a}$ & Ovarian, peritoneal, & JM8 AUC 6 & neutropenia \\
\hline & & tubal cancer & PLD $40 \mathrm{mg} / \mathrm{m}^{2}, \mathrm{q} 28$ & thrombocytopenia \\
\hline & & & & abdominal pain emesis, DVT \\
\hline \multirow[t]{2}{*}{ Recchia $^{28}$} & 20 & Ovarian cancer & OXA $120 \mathrm{mg} / \mathrm{m}^{2}$ & neutropenia \\
\hline & & & PLD 40 mg/m², q2। & thrombocytopenia \\
\hline
\end{tabular}

Abbreviations: CDDP, cisplatin; DLT, dose limiting toxicity; DVT, deep venous thromboembolism; JM8, carboplatin; MTD, maximum tolerated dose; OXA, oxaliplatin; q, every; d, day. ${ }^{a} 24$ cases for phase I, 12 cases for confirmatory study. 
Table 3 Phase I studies with pegylated liposomal doxorubicin (PLD) in combination with taxanes

\begin{tabular}{|c|c|c|c|c|}
\hline Author & No.pts & Type of tumor & MTD & DLTs \\
\hline \multirow[t]{2}{*}{$\mid$ |srael ${ }^{29}$} & - & Solid tumors & PTX I 35 mg/m², dl,8 & mucositis, skin toxicity \\
\hline & & & PLD $30 \mathrm{mg} / \mathrm{m}^{2} \mathrm{dl}$, q28 & neutropenia \\
\hline \multirow[t]{2}{*}{ Muggia ${ }^{30}$} & 25 & Endometrial cancer & PTX $75 \mathrm{mg} / \mathrm{m}^{2}, \mathrm{dl}, 8,15$ & HFS \\
\hline & & & PLD 24 mg/m², dl, q28 & neutropenia \\
\hline \multirow[t]{2}{*}{ Modiano ${ }^{31}$} & 32 & Breast, & PTX $175 \mathrm{mg} / \mathrm{m}^{2}$ & HFS \\
\hline & & gynecologic tumors & PLD 30 mg/m², q2I & neutropenia \\
\hline \multirow[t]{2}{*}{ Schwonzen ${ }^{32}$} & 21 & $\mathrm{MBC}$ & PTX $80 \mathrm{mg} / \mathrm{m}^{2}$ weekly & mucositis, skin toxicity \\
\hline & & & PLD 15 mg/m², q 15 & alopecia, neurotoxicity \\
\hline \multirow[t]{5}{*}{ Tolis $^{33}$} & 21 & - & PTX $85 \mathrm{mg} / \mathrm{m}^{2}, \mathrm{dl}, 8,15$ & neutropenia \\
\hline & & & PLD 30 mg/m², dl, q28 & \\
\hline & & & or & \\
\hline & & & PTX $70 \mathrm{mg} / \mathrm{m}^{2}, \mathrm{dl}, 8,15$ & \\
\hline & & & PLD 35 mg/m², dl, q28 & \\
\hline \multirow[t]{2}{*}{ Androulakis ${ }^{34}$} & 19 & Solid tumors & PTX $80 \mathrm{mg} / \mathrm{m}^{2}, \mathrm{dI}, 8,15,2 \mathrm{I}$ & neutropenia \\
\hline & & & PLD $10 \mathrm{mg} / \mathrm{m}^{2}, \mathrm{dl}, 8,15,21, \mathrm{q} 42$ & diarrhea \\
\hline \multirow[t]{2}{*}{ Mavroudis $^{35}$} & 26 & Solid tumors & PTX II $5 \mathrm{mg} / \mathrm{m}^{2}, \mathrm{~d} 2$ & neutropenia \\
\hline & & & PLD I 5 mg/m², dl, ql5 & \\
\hline \multirow[t]{2}{*}{ Lortholary ${ }^{36}$} & 16 & $\mathrm{MBC}$ & PTX 80 mg $/ \mathrm{m}^{2}$, weekly & - \\
\hline & & & PLD I $2.5-22.5 \mathrm{mg} / \mathrm{m}^{2}$, q 15 & \\
\hline \multirow[t]{5}{*}{ Briasoulis $^{37}$} & 44 & Solid tumors & PTX $80 \mathrm{mg} / \mathrm{m}^{2} \mathrm{dl}, 8,15$ & DVT \\
\hline & & & PLD 35 mg/m² q28 & HFS \\
\hline & & & or & neutropenia \\
\hline & & & PTX $90 \mathrm{mg} / \mathrm{m}^{2} \mathrm{dl}, 8,15$ & \\
\hline & & & PLD 30 mg/m² q28 & \\
\hline \multirow[t]{2}{*}{ Hirsch $^{38}$} & 17 & Solid tumors & DTX 67.5 mg/m², dl & Stomatitis, neutropenia \\
\hline & & & PLD $30 \mathrm{mg} / \mathrm{m}^{2}, \mathrm{dl}$, q2I & thrombocytopenia \\
\hline \multirow[t]{2}{*}{ Drinkard ${ }^{39}$} & 6 & Solid tumors & DTX $50 \mathrm{mg} / \mathrm{m}^{2}, \mathrm{~d} 5$ & esophagitis \\
\hline & & & PLD 30 mg/m², dl, q2I/28 & neutropenia \\
\hline \multirow[t]{2}{*}{ Pavlick $^{40}$} & 26 & Solid tumors & DTX $80 \mathrm{mg} / \mathrm{m}^{2}$ & HFS \\
\hline & & & PLD $30 \mathrm{mg} / \mathrm{m}^{2}, \mathrm{q} 21+\mathrm{GF}$ & neutropenia \\
\hline \multirow[t]{2}{*}{ Tauer ${ }^{41}$} & 21 & Solid tumors & DTX $70 \mathrm{mg} / \mathrm{m}^{2}$ & neutropenia \\
\hline & & & PLD $40 \mathrm{mg} / \mathrm{m}^{2}, \mathrm{q} 28$ & \\
\hline \multirow[t]{5}{*}{ Sparano ${ }^{42}$} & 41 & Breast cancer & DTX $60 \mathrm{mg} / \mathrm{m}^{2}$ & neutropenia \\
\hline & & & PLD $30 \mathrm{mg} / \mathrm{m}^{2}, \mathrm{q} 21$ & \\
\hline & & & or & \\
\hline & & & DTX $75 \mathrm{mg} / \mathrm{m}^{2}$ & \\
\hline & & & PLD $30 \mathrm{mg} / \mathrm{m}^{2}, \mathrm{q} 28+\mathrm{GF}$ & \\
\hline \multirow[t]{2}{*}{ Sikov 43} & 22 & Solid tumors & DTX 25 mg/m², dI,8, I5 & mucositis, diarrhea \\
\hline & & & PLD 20 mg/m², dl, q28 & neutropenia \\
\hline \multirow[t]{2}{*}{ Gasparini ${ }^{44}$} & 15 & Breast cancer & DTX 35 mg/m², d2,9 & skin toxicity \\
\hline & & & PLD 35 mg/m², dI, q2I & neutropenia \\
\hline \multirow[t]{2}{*}{ Fracasso ${ }^{45}$} & 22 & Solid tumors & DTX $40 \mathrm{mg} / \mathrm{m}^{2}$ & skin toxicity \\
\hline & & & PLD 20 mg/m², bi-weekly & thrombocytopenia \\
\hline \multirow[t]{2}{*}{ Bischoff ${ }^{46}$} & 12 & $\mathrm{MBC}$ & DTX $30 \mathrm{mg} / \mathrm{m}^{2}, \mathrm{dI}, 8,15$ & neutropenia \\
\hline & & & PLD 40 mg/m², dl, q28 & \\
\hline
\end{tabular}

Abbreviations: DLT, dose limiting toxicity; DTX, docetaxel; DVT, deep venous thromboembolism; GF, growth factor support; HFS, hand-foot syndrome; MBC, metastatic breast cancer; MTD, maximum tolerated dose; PTX, paclitaxel; q, every; d, day.

When considering the studies including only or a very large proportion of platinum-resistant patients, the response rates ranged from $9.1 \%$ to $40.0 \%$, and did not seem to present a schedule or dose dependence, although the relatively small sample series, and also patients' heterogeneity in terms of the number of previously administered lines of chemotherapy, are a major limit to reliable comparisons.
In particular, several studies have shown that a more acceptable toxicity profile in terms of decreased rates of HFS and stomatitis/mucositis can be obtained with a PLD dose of $40 \mathrm{mg} / \mathrm{m}^{2}$ every 28 days, with comparable response rates and outcome. ${ }^{67,74,75}$

More recently, biweekly schedules have also been investigated in the same clinical setting in order to further improve 
Table 4 Phase I studies with pegylated liposomal doxorubicin (PLD) in combination with platinum/taxanes

\begin{tabular}{|c|c|c|c|c|}
\hline Author & No.pts & Type of tumor & MTD & DLTs \\
\hline \multirow[t]{3}{*}{ Eng $^{47}$} & 23 & Solid tumors & CDDP $60 \mathrm{mg} / \mathrm{m}^{2}$ & neutropenia \\
\hline & & & PTX $90 \mathrm{mg} / \mathrm{m}^{2}$ (I cycle) then $130 \mathrm{mg} / \mathrm{m}^{2}$ & \\
\hline & & & PLD $30 \mathrm{mg} / \mathrm{m}^{2}$, q21 & \\
\hline \multirow[t]{3}{*}{$\operatorname{Rose}^{48}$} & 12 & Ovarian, tubal peritoneal cancer & JM8 AUC 5 & neutropenia \\
\hline & & & PTX 175 mg/m², q2I & \\
\hline & & & PLD $30 \mathrm{mg} / \mathrm{m}^{2}$, every other cycle & \\
\hline \multirow[t]{7}{*}{ Gibbs $^{49}$} & 31 & Ovarian carcinomas and MMMT & JM8 AUC 6 & neutropenia \\
\hline & & & PTX $175 \mathrm{mg} / \mathrm{m}^{2}$ & stomatitis \\
\hline & & & PLD $30 \mathrm{mg} / \mathrm{m}^{2}, \mathrm{q} 28$ & HFS \\
\hline & & & or & \\
\hline & & & JM8 AUC 5 & \\
\hline & & & PTX $175 \mathrm{mg} / \mathrm{m}^{2}$ & \\
\hline & & & PLD 20 mg/m², q2I & \\
\hline
\end{tabular}

Abbreviations: CDDP, cisplatin; DLT, dose limiting toxicity; HFS, hand-foot syndrome; JM8, carboplatin; MMMT, mixed malignant Müllerian tumors; MTD, maximum tolerated dose; PTX, paclitaxel; q, every; d, day.

the toxicity pattern. ${ }^{77-79}$ Although the direct comparison across non-randomized phase II studies is difficult, it seems that the biweekly regimen represents a good therapeutic option since it does not worsen clinical outcome while preventing severe hematological and non-hematological side effects. ${ }^{80}$ Results relative to platinum-sensitive recurrent ovarian cancer patients are not informative or refer to very low numbers of cases. ${ }^{69,76,78}$

The demonstrated efficacy of PLD in the poor prognosis subset of recurrent platinum-resistant ovarian cancer has supported the investigation of PLD/platinum doublets also in platinum-sensitive disease in which the currently administered partners of platinum agents are generally associated with elevated neurologic and hematological toxicity. ${ }^{81,82}$ As shown in Table 7 , the association of PLD $\left(50 \mathrm{mg} / \mathrm{m}^{2}\right)$ with CDDP $\left(60 \mathrm{mg} / \mathrm{m}^{2}\right)$ was investigated in a 28-day schedule by Tas et al, ${ }^{83}$ who reported an overall response rate of $62.0 \%$ with $4(19.0 \%)$ complete, and $9(43.0 \%)$ partial responses. Although this schedule was well tolerated (only $10 \%$ grade 2 neurotoxicity, and grade 3/4 anemia, neutropenia, and HFS accounting for $18 \%, 41 \%$, and $9 \%$, respectively), PLD/JM8 combinations are considered more manageable due to the

Table 5 Phase I studies with pegylated liposomal doxorubicin (PLD) in combination with topotecan (TPT)

\begin{tabular}{|c|c|c|c|c|}
\hline Author & No.pts & Type of tumor & MTD & DLTs \\
\hline \multirow[t]{2}{*}{ Ryan $^{50}$} & 9 & Ovarian & TPT $1.0 \mathrm{mg} / \mathrm{m}^{2}, \mathrm{dl}-5$ & neutropenia \\
\hline & & cancer & PLD 20 mg/m², q28 & thrombocytopenia \\
\hline \multirow{2}{*}{ Yeung ${ }^{51}$} & 15 & Solid & TPT $1.0 \mathrm{mg} / \mathrm{m}^{2}, \mathrm{dl}-5$ & mucositis \\
\hline & & tumors & PLD 30 mg/m², q2। & neutropenia \\
\hline \multirow[t]{2}{*}{ Hochster ${ }^{52}$} & 17 & Solid & TPT $0.4 \mathrm{mg} / \mathrm{m}^{2}, \mathrm{dl}-2 \mathrm{I}$ & neutropenia \\
\hline & & tumors & PLD 30 mg/m², q28 & \\
\hline \multirow[t]{2}{*}{ Hamilton $^{53}$} & 27 & Solid & TPT $0.4 \mathrm{mg} / \mathrm{m}^{2}, \mathrm{dl}-2 \mathrm{I}$ & neutropenia \\
\hline & & tumors & PLD 30 mg/m², q28 & \\
\hline \multirow[t]{2}{*}{ Geertsen $^{54}$} & 20 & Ovarian & TPT 0.75 mg/m², dl -5 & neutropenia \\
\hline & & cancer & PLD $30 \mathrm{mg} / \mathrm{m}^{2}, \mathrm{~d} 8, \mathrm{q} 35$ & \\
\hline \multirow[t]{2}{*}{ Pautier 55} & 16 & Solid & TPT $0.5 \mathrm{mg} / \mathrm{m}^{2}, \mathrm{dl}-5$ & neutropenia \\
\hline & & tumors & PLD 35 mg/m², q28 & \\
\hline \multirow[t]{2}{*}{ Mirchandani ${ }^{56}$} & 21 & Ovarian & TPT $0.4 \mathrm{mg} / \mathrm{m}^{2}, \mathrm{dl}-14$ & neutropenia \\
\hline & & cancer & PLD 40 mg/m², q28 & thrombocytopenia \\
\hline \multirow[t]{2}{*}{ Garcia $^{57}$} & 32 & Solid & TPT $1.0 \mathrm{mg} / \mathrm{m}^{2}, \mathrm{dl}-3$ & neutropenia \\
\hline & & tumors & PLD $40 \mathrm{mg} / \mathrm{m}^{2}, \mathrm{~d} 4$, q28 & I death \\
\hline \multirow[t]{2}{*}{ Ghesquieres $^{58}$} & 23 & Solid & TPT $0.5 \mathrm{mg} / \mathrm{m}^{2}, \mathrm{dl}-5$ & neutropenia \\
\hline & & tumors ( $84 \%$ ovarian cancer) & PLD 35 mg/m², dl, q28 & \\
\hline \multirow[t]{3}{*}{$\operatorname{Rose}^{59}$} & 22 & Ovarian, tubal & TPT $1.5 \mathrm{mg} / \mathrm{m}^{2}, \mathrm{dl}-5$ per os & neutropenia \\
\hline & & peritoneal & PLD 40 mg/m², dl, q28 & \\
\hline & & cancer & & \\
\hline \multirow[t]{2}{*}{ Penson ${ }^{60}$} & 18 & Müllerian & TPT 0.5 mg/m², dl-3 & neutropenia \\
\hline & & tumors & PLD $30 \mathrm{mg} / \mathrm{m}^{2}, \mathrm{dl}, \mathrm{q} 2 \mathrm{I}$ & \\
\hline
\end{tabular}

Abbreviations: DLT, dose limiting toxicity; MTD, maximum tolerated dose;TPT, topotecan; q, every; d, day. 
Table 6 Phase II studies with pegylated liposomal doxorubicin as single agent

\begin{tabular}{|c|c|c|c|c|c|c|c|c|}
\hline \multirow[t]{2}{*}{ Author } & \multirow[t]{2}{*}{ Dose, schedule } & \multirow{2}{*}{$\begin{array}{l}\text { Clinical } \\
\text { setting }\end{array}$} & \multirow{2}{*}{$\begin{array}{l}\mathbf{R R} \\
\text { (\%) }\end{array}$} & \multirow{2}{*}{$\begin{array}{l}\text { PFS (Median) } \\
\text { months }\end{array}$} & \multicolumn{4}{|c|}{ Grade 3/4 toxicity/patient } \\
\hline & & & & & Hgb & Neu & PLT & HFS \\
\hline Muggia $^{65}$ & $50 \mathrm{mg} / \mathrm{m}^{2}, \mathrm{q} 2 \mathrm{l}$ & RES 35 & 25.7 & 5.7 & - & - & - & - \\
\hline \multirow[t]{2}{*}{ Gordon ${ }^{66}$} & $50 \mathrm{mg} / \mathrm{m}^{2}, \mathrm{q} 2 \mathrm{I}$ & ALL 89 & 16.8 & 4.8 & 20.2 & 15.7 & 2.2 & 20.2 \\
\hline & & RES 82 & 18.3 & 4.4 & & & & \\
\hline \multirow[t]{2}{*}{$\operatorname{Rose}^{67}$} & $50 \mathrm{mg} / \mathrm{m}^{2}, \mathrm{q} 28$ & RES 37 & 13.5 & 4.0 & - & - & - & - \\
\hline & $40 \mathrm{mg} / \mathrm{m}^{2}, \mathrm{q} 28$ & RES 39 & 7.7 & 4.0 & & & & \\
\hline Arcuri ${ }^{68}$ & $50 \mathrm{mg} / \mathrm{m}^{2}, \mathrm{q} 28$ & ALL 30 & 26.6 & - & - & 23.3 & - & 10.0 \\
\hline \multirow[t]{2}{*}{ Katsumata ${ }^{69}$} & $50 \mathrm{mg} / \mathrm{m}^{2}, \mathrm{q} 28$ & RES 63 & 20.9 & 5.6 & 17.6 & 67.5 & 6.9 & 16.2 \\
\hline & & SEN II & 27.3 & 5.3 & & & & \\
\hline Gorumlu 70 & $50 \mathrm{mg} / \mathrm{m}^{2}, \mathrm{q} 28$ & RES 17 & 17.0 & 3.7 & - & 12.0 & - & 6.0 \\
\hline Steppan ${ }^{71}$ & $45 \mathrm{mg} / \mathrm{m}^{2}, \mathrm{q} 28$ & RES 29 & 30.5 & - & - & - & - & - \\
\hline $\mathrm{Chou}^{72}$ & $45 \mathrm{mg} / \mathrm{m}^{2}, \mathrm{q} 28$ & RES 29 & 23.1 & 5.4 & - & - & - & - \\
\hline Markman ${ }^{73}$ & $40 \mathrm{mg} / \mathrm{m}^{2}, \mathrm{q} 28$ & RES 44 & 9.1 & - & - & 2.0 & 0 & 0 \\
\hline \multirow[t]{3}{*}{ Campos $^{74}$} & $40 \mathrm{mg} / \mathrm{m}^{2}, \mathrm{q} 28$ & ALL 72 & 27.0 & 5.3 & 11 & 2 & 1 & - \\
\hline & & RES 29 & 29.0 & & & & & \\
\hline & & SEN 43 & 25.6 & & & & & \\
\hline Wilailak $^{75}$ & $40 \mathrm{mg} / \mathrm{m}^{2}, \mathrm{q} 21$ & RES I4 & 23.0 & 6.0 & 0 & 14.3 & 0 & 2.0 \\
\hline \multirow[t]{3}{*}{ Lorusso $^{76}$} & $35 \mathrm{mg} / \mathrm{m}^{2}, \mathrm{q} 2 \mathrm{I}$ & ALL & 13.5 & 7.2 & 0 & 10.8 & 0 & 2.7 \\
\hline & & $\operatorname{RES} 17^{\circ}$ & 18.9 & - & & & & \\
\hline & & SEN 20 & 10.0 & - & & & & \\
\hline Strauss $^{77}$ & $20 \mathrm{mg} / \mathrm{m}^{2}$, q 15 & RES 50 & 40 & 4.1 & 0 & 4 & 0 & 2.0 \\
\hline \multirow[t]{2}{*}{ Oskay-Oezcelik ${ }^{78}$} & $20 \mathrm{mg} / \mathrm{m}^{2}$, q 15 & RES 7 & 0 & 2.3 & 5 & 0 & 0 & 5.0 \\
\hline & & SEN 13 & 7.7 & 4.1 & & & & \\
\hline \multirow[t]{3}{*}{ Sehouli ${ }^{79}$} & $20 \mathrm{mg} / \mathrm{m}^{2}, \mathrm{q} 15$ & ALL 64 & $10.9^{b}$ & 4.3 & 4.7 & 0 & 1.6 & 4.7 \\
\hline & & RES 21 & - & - & & & & \\
\hline & & SEN 43 & - & - & & & & \\
\hline
\end{tabular}

Abbreviations: ALL, ; HFS, hand-foot syndrome; Hgb, anemia; PFS, progression-free survival; RR, response rate; RES, platinum-resistant recurrent disease; Neu, neutropenia, PLT, platelet toxicity; SEN, platinum-sensitive recurrent disease; q, every; d, day.

aPlatinum sensitivity according to the cut-off of 12 -month platinum free interval; ${ }^{b}$ ln assessed patients $(n=44)$.

expected lower neurotoxicity. ${ }^{84-89}$ In 2007 Ferrero et al ${ }^{87}$ evaluated PLD $\left(30 \mathrm{mg} / \mathrm{m}^{2}\right)$ followed by JM8 (AUC 5), every 28 days, in 104 patients, of whom 53 were totally and 43 were partially platinum sensitive: overall, the objective response rate was $62.5 \%$, with a $38 \%$ rate of complete response; median progression-free survival (PFS) and OS were 9.4 months, and 32 months, respectively. Comparable rates of response were achieved in the study by duBois et $\mathrm{al}^{87}$ who reported an objective response rate of $68 \%$ in 67 recurrent ovarian cancer patients.

Since platinum sensitivity is more likely to be a continuum instead of being defined by operational time-based cut-off points, it is not surprising that much interest has been focused on that subset of partially platinum $=$ sensitive patients which show a substantially similar rate of response to platinum, as well as to non-platinum agents, ${ }^{6}$ thus questioning if they should really be considered as partially platinum sensitive or partially platinum resistant. The studies by Ferrero et al ${ }^{87}$ and by Weber et al ${ }^{89}$ do not report the specific response rates in partially vs totally platinum-sensitive disease, but median PFS was longer in the latter group in both studies. The same trend has been reported by Rapoport et al, ${ }^{86}$ who documented in the whole population an overall response rate of $67.5 \%$, but clearly distinguished totally vs partially sensitive patients (response rate $=81.0 \%$ vs $52.6 \%$; median PFS $=15.1$ vs 9.7 months, respectively).

The largest phase II study $(\mathrm{n}=58)$ specifically focusing on partially sensitive recurrent ovarian cancer reported an overall response rate of $46 \%$ ( $4 \%$ complete and $42 \%$ partial responses), with an additional $33 \%$ of cases experiencing disease stabilization longer than 6 months. ${ }^{88}$ For those patients with measurable Ca125 levels, the response rate was $66 \%$ (28\% complete and $38 \%$ partial responses), with an additional $18 \%$ of cases experiencing disease stabilization longer than 6 months. Median PFS was 10 months, and median OS 19.1 months. On the basis of the present literature, it seems that phase III randomized studies comparing platinum-based vs non-platinum agents in this clinical subset are urgently needed in order to correctly allocate patients to salvage treatment. In this context, a multicentric phase III study (MITO-8, NCT00657878) has been recently launched comparing PLD (40 mg/m² every 28 days) vs JM8/PTX 
Table 7 Non-randomized studies with combinations of pegylated liposomal doxorubicin (PLD) and platinum agents

\begin{tabular}{|c|c|c|c|c|c|c|c|c|c|}
\hline \multirow[t]{2}{*}{ Author } & \multirow[t]{2}{*}{ Drugs/dose } & \multirow{2}{*}{$\begin{array}{l}\text { PFI } \\
\text { mts }\end{array}$} & \multirow[t]{2}{*}{ No.pts } & \multirow{2}{*}{$\begin{array}{l}\text { RR } \\
\text { (\%) }\end{array}$} & \multirow{2}{*}{$\begin{array}{l}\text { PFS } \\
\text { mts }\end{array}$} & \multicolumn{4}{|c|}{$\%$ Grade $3 / 4$ toxicity/patient } \\
\hline & & & & & & Hgb & Neu & PLT & HFS \\
\hline \multirow[t]{2}{*}{$\operatorname{Tas}^{83}$} & PLD $\left(50 \mathrm{mg} / \mathrm{m}^{2}\right) \mathrm{dl}$ & $\geq 6$ & 22 & 62.0 & - & 18 & 41 & 0 & 9 \\
\hline & $\operatorname{CDDP}\left(60 \mathrm{mg} / \mathrm{m}^{2}\right) \mathrm{dl}, \mathrm{q} 28$ & & & & & & & & \\
\hline \multirow[t]{2}{*}{ Vorobiof ${ }^{34}$} & PLD $\left(50 \mathrm{mg} / \mathrm{m}^{2}\right) \mathrm{dl}$ & $\geq 6$ & 29 & 76.2 & & 9 & 52.3 & 38 & 9.5 \\
\hline & JM8 (AUC 5) dl, q28 & & & & & & & & \\
\hline \multirow[t]{2}{*}{ du Bois ${ }^{85}$} & PLD $\left(40 \mathrm{mg} / \mathrm{m}^{2}\right) \mathrm{dl}$ & $\geq 6$ & 67 & 68 & 11.6 & 8 & 24 & 14 & 7 \\
\hline & JM8 (AUC 6) dl, q28 & & & & & & & & \\
\hline \multirow[t]{3}{*}{ Rapoport ${ }^{86}$} & $\operatorname{PLD}\left(50 \mathrm{mg} / \mathrm{m}^{2}\right) \mathrm{dl}$ & All & 40 & 67.5 & 11.9 & 10 & 55 & 42.5 & 7.5 \\
\hline & JM8 (AUC 5) dl, q28 & $7-12$ & 19 & 52.6 & 9.7 & & & & \\
\hline & & $>12$ & 21 & 81.0 & 15.1 & & & & \\
\hline \multirow[t]{3}{*}{ Ferrero ${ }^{87}$} & PLD $\left(30 \mathrm{mg} / \mathrm{m}^{2}\right) \mathrm{dl}$ & All & 96 & 62.5 & 9.4 & 12 & 51 & 26 & 0 \\
\hline & JM8 (AUC 5) dl, q28 & $7-12$ & 43 & - & 7.9 & & & & \\
\hline & & $>12$ & 53 & - & 11.4 & & & & \\
\hline \multirow[t]{2}{*}{ Power ${ }^{88}$} & PLD $\left(30 \mathrm{mg} / \mathrm{m}^{2}\right) \mathrm{dl}$ & $7-12$ & 58 & 46 & 10 & 7 & 21 & 17 & 1.7 \\
\hline & JM8 (AUC 5) dl, q28 & & & & & & & & \\
\hline \multirow[t]{3}{*}{ Weber ${ }^{89}$} & PLD $\left(30 \mathrm{mg} / \mathrm{m}^{2}\right) \mathrm{dl}$ & $\geq 6$ & 81 & 65.4 & 13.6 & 13.0 & 55.0 & 29.0 & 1.0 \\
\hline & JM8 (AUC 5) dl, q28 & $6-12$ & 32 & - & 9.8 & & & & \\
\hline & & $\geq 12$ & 49 & - & 14.4 & & & & \\
\hline \multirow[t]{2}{*}{ Nicoletto 90} & PLD $\left(30 \mathrm{mg} / \mathrm{m}^{2}\right) \mathrm{dI}$ & $<6$ & 14 & 28.6 & 5.9 & 0 & 9.3 & 0 & 0 \\
\hline & OXA $\left(70 \mathrm{mg} / \mathrm{m}^{2}\right) \mathrm{dl}, \mathrm{q} 28$ & $\geq 6$ & 29 & 66.7 & 9.9 & & & & \\
\hline \multirow[t]{2}{*}{ Recchia91 } & PLD $\left(20 \mathrm{mg} / \mathrm{m}^{2}\right) \mathrm{dl}, 2$ & $<6$ & 13 & 32.5 & 5.8 & 5 & 38 & 8 & 0 \\
\hline & OXA $\left(60 \mathrm{mg} / \mathrm{m}^{2}\right) \mathrm{dl}, 2, \mathrm{q} 2 \mathrm{l}$ & $\geq 6$ & 27 & 67.5 & 12.1 & & & & \\
\hline \multirow[t]{3}{*}{ Valerio ${ }^{92}$} & $\operatorname{PLD}\left(30 \mathrm{mg} / \mathrm{m}^{2}\right)$ & $<6$ & 27 & 37.0 & 7 & 17 & 15 & 15 & 0 \\
\hline & OXA $\left(85 \mathrm{mg} / \mathrm{m}^{2}\right)$ & $\geq 6$ & 12 & 66.3 & 8.5 & & & & \\
\hline & cyclophosphamide $\left(750 \mathrm{mg} / \mathrm{m}^{2}\right)$ & & & & & & & & \\
\hline
\end{tabular}

Abbreviations: CDDP, cisplatin; HFS, hand-foot syndrome; Hgb, anemia; JM8, carboplatin; Neu, neutropenia; PFI, platinum-free interval; PFS, progression-free survival; PLT, platelet toxicity; RR, response rate; OXA, oxaliplatin; q, every; d, day.

(AUC 5, $175 \mathrm{mg} / \mathrm{m}^{2}$ ) with cross-over on progression in OvCa patients recurring within 6 to 12 months from the completion of primary treatment.

Overall, the toxicity rate/severity related to combinations of PLD and JM8 was consistent across the studies, with grade $3 / 4$ anemia ranging from $7 \%$ to $13 \%,{ }^{84-89}$ and grade $3 / 4$ neutropenia occurring in around $50 \%$ of cases with the exception of two studies. ${ }^{86,88}$ The rate of severe thrombocytopenia seems closely related to PLD dosage: indeed, in studies using PLD at 30 to $40 \mathrm{mg} / \mathrm{m}^{2}$, grade 3/4 thrombocytopenia remained within $14 \%$ and $26 \%$, while at PLD doses of $50 \mathrm{mg} / \mathrm{m}^{2}$ it increased to approximately $40 \%$. As expected, severe HFS was negligible in studies using PLD at a dosage of $30 \mathrm{mg} / \mathrm{m}^{2} .{ }^{87-89}$

Combinations of PLD with OXA seem very promising since the reported rates of response appear in the range of those reported with PLD/JM8 combinations. ${ }^{90-92}$ Moreover, with the limits of the sample size, a very acceptable rate of stomatitis/ mucositis and HFS has been shown, likely due to the use of the PLD at the dosage of $30 \mathrm{mg} / \mathrm{m}^{2}$, every $21 / 28$ days.

For neurotoxicity, grade 2 sensory neuropathy was reported in $7 \%$ of cases in the study by Nicoletto et $\mathrm{al}^{90}$ which seems quite an acceptable figure considering that $37 \%$ of patients had already received $>1$ previous lines of chemotherapy; $77 \%$ of patients had also been administered prior platinum/ taxanes. However, a high rate of grade 2 neurotoxicity was documented by Recchia et $\mathrm{al}^{91}$ whose study, nevertheless, used a cumulative OXA dosage of $120 \mathrm{mg} / \mathrm{m}^{2}$.

Attempts to add PLD to combinations of two drugs have been also reported: in particular, Valerio et a ${ }^{12}$ explored the combination PLD $\left(30 \mathrm{mg} / \mathrm{m}^{2}\right)$, OXA $\left(85 \mathrm{mg} / \mathrm{m}^{2}\right)$, and cyclophosphamide $\left(750 \mathrm{mg} / \mathrm{m}^{2}\right)$ on a 3-week schedule in a series of 39 recurrent ovarian cancer patients (12 platinum sensitive, 27 platinum resistant). The response rate was $66.3 \%$ in platinum-sensitive (median PFS 8.5 months), and 37\% in platinum-resistant (median PFS $=7$ months). Overall, the regimen was well tolerated with grade 2 neurotoxicity observed in $20 \%$ of patients, and grade $3 / 4$ anemia, neutropenia, and thrombocytopenia documented in $17 \%, 15 \%$, and $15 \%$ of cases, respectively. Severe HFS was not reported.

Finally, a phase II front-line study (S9912) has been recently conducted by the Southwest Oncology Group, which investigated the addition of intravenous (iv) PLD (30 to $40 \mathrm{mg} / \mathrm{m}^{2}$, day $8, \times 2$ cycles) to intraperitoneal (ip) CDDP 
(75 $\mathrm{mg} / \mathrm{m}^{2}$, day 2 , every 21 days), and both iv and ip paclitaxel $\left(135 \mathrm{mg} / \mathrm{m}^{2}\right.$, day 1 , every 21 days, and $60 \mathrm{mg} / \mathrm{m}^{2}$, day 8 , every 21 days, respectively). ${ }^{93}$ This regimen gave clinical outcome measures similar to those reported in comparable patient populations treated with classical CDDP-containing combinations; however, an unacceptable rate of severe toxicity ( 5 treatment related deaths, and 32 patients with at least on grade 3-5 toxicity) was documented, thus discouraging any further development.

One of the most frequently studied partners in PLD-based combination is represented by gemcitabine (GEM), on the basis of the demonstrations of the synergistic antiproliferative activity of the drugs, and of their non overlapping toxicity profiles. As summarized in Table 8 , in the subset of platinum resistant disease the response rate range from 22 to $33 \%$, with median PFS from 2.7 to 6.0 months regardless of the schedule administered. ${ }^{94-100}$

Considering that the percentage of patients who had already received $>1$ lines of chemotherapy was high in some studies, ${ }^{99,100}$ the regimen was relatively well tolerated: indeed, grade $3 / 4$ anemia was documented at $3 \%$ to $9 \%$ in studies using the classical 3-week and 4-week schedules, increasing up to $17 \%$ in the only study using the bi-weekly schedule. ${ }^{94}$ Grade 3/4 neutropenia was negligible in bi-weekly regimens but increased up to $30 \%$ in the 3-week schedule..$^{99,100}$ The rate of grade 3/4 thrombocytopenia was consistent across all studies, at around $9 \%$ to $10 \%$, while a wide heterogeneity in the rate of severe HFS was noted. However, it has to be taken into account that the two studies reporting $>10 \%$ grade $3 / 4$ HFS $^{99,100}$ included heavily pretreated patients in $>50 \%$ of the sample series: indeed, evidence has been reported that the incidence of HFS is correlated with the presence of neuropathy and also with the number of previous chemotherapy regimens, regardless of type of chemotherapeutic agent used. ${ }^{101}$

Some phase II studies explored the efficacy of PLD associated with topotecan, ${ }^{102}$ as well as PTX, ${ }^{103}$ vinolrebine, ${ }^{104}$ and ifosphamide. ${ }^{105}$ Overall, the rate of response ranged from $28 \%$ to $37 \%$ with a median PFS of 5.5 to 7.5 months, figures

Table 8 Non-randomized studies with combinations of pegylated liposomal doxorubicin (PLD) and non-platinum agents

\begin{tabular}{|c|c|c|c|c|c|c|c|c|}
\hline \multirow[t]{2}{*}{ Author } & \multirow[t]{2}{*}{ Drugs/dose } & \multirow[t]{2}{*}{ No. } & \multirow{2}{*}{$\begin{array}{l}\mathbf{R R} \\
\text { (\%) }\end{array}$} & \multirow{2}{*}{$\begin{array}{l}\text { PFS } \\
\text { mts }\end{array}$} & \multicolumn{4}{|c|}{$\%$ Grade $3 / 4$ toxicity/patient } \\
\hline & & & & & Hgb & Neu & PLT & HFS \\
\hline \multirow[t]{2}{*}{$\mathrm{Tas}^{94}$} & PLD $\left(20 \mathrm{mg} / \mathrm{m}^{2}\right) \mathrm{dl}, 15$ & RES I8 & 28.0 & - & 16.7 & 0 & 0 & 5.5 \\
\hline & GEM $\left(2000 \mathrm{mg} / \mathrm{m}^{2}\right) \mathrm{dl}, \mathrm{I} 5 \mathrm{q} 28$ & & & & & & & \\
\hline \multirow[t]{2}{*}{ Skarlos 95} & PLD $\left(25 \mathrm{mg} / \mathrm{m}^{2}\right) \mathrm{dl}$ & RES 37 & 22 & 2.7 & - & - & - & 2.7 \\
\hline & GEM $\left(650 \mathrm{mg} / \mathrm{m}^{2}\right) \mathrm{d}$,, $8 \mathrm{q} 28$ & & & & & & & \\
\hline \multirow[t]{2}{*}{ Holloway96 } & PLD $\left(25 \mathrm{mg} / \mathrm{m}^{2}\right) \mathrm{dl}$ & ALL 25 & 64.0 & - & - & 24.0 & 4.0 & - \\
\hline & $\operatorname{GEM}\left(650 \mathrm{mg} / \mathrm{m}^{2}\right) \mathrm{dl}, 8$ & & & & & & & \\
\hline \multirow[t]{2}{*}{ Karaoglu97 } & PLD $\left(25 \mathrm{mg} / \mathrm{m}^{2}\right) \mathrm{dl}$ & RES 35 & 28.6 & 6 & 2.9 & 8.6 & - & 0 \\
\hline & GEM $\left(1000 \mathrm{mg} / \mathrm{m}^{2}\right) \mathrm{dl}, 8 \mathrm{q} 28$ & & & & & & & \\
\hline \multirow[t]{2}{*}{ Petru $^{98}$} & PLD $\left(30 \mathrm{mg} / \mathrm{m}^{2}\right) \mathrm{dl}$ & RES 3I & 33.0 & 3.8 & 3.0 & 26.0 & 10 & 3.0 \\
\hline & $\operatorname{GEM}\left(650 \mathrm{mg} / \mathrm{m}^{2}\right) \mathrm{d} \mathrm{I}, 8 \mathrm{q} 28$ & & & & & & & \\
\hline \multirow[t]{2}{*}{ D'Agostino 99} & PLD $\left(30 \mathrm{mg} / \mathrm{m}^{2}\right), \mathrm{dl}$ & RES 36 & 25.0 & - & 7.0 & 32.6 & 8.5 & 10 \\
\hline & GEM (I000 mg/m²), dl,8 q2 I & SEN 3I & 45.2 & & & & & \\
\hline \multirow[t]{2}{*}{ Ferrandina ${ }^{100}$} & PLD $\left(30 \mathrm{mg} / \mathrm{m}^{2}\right), \mathrm{dl}$ & RES 66 & 21.6 & 5 & 9.0 & 28.8 & 10.8 & 14.4 \\
\hline & GEM (I000 mg/m²), dl,8 q2। & SEN 45 & 53.7 & 8.7 & & & & \\
\hline \multirow[t]{4}{*}{ Verhaar-Langereis ${ }^{102}$} & PLD $\left(30 \mathrm{mg} / \mathrm{m}^{2}\right), \mathrm{dl}$ & RES 27 & 28.0 & 7.5 & - & $70.4^{a}$ & 48.1 & 44.4 \\
\hline & TPT $\left(1.0 \mathrm{mg} / \mathrm{m}^{2}\right), \mathrm{dl}-5 \mathrm{q} 2 \mathrm{l}$ & & & & & & & \\
\hline & and PLD $\left(40 \mathrm{mg} / \mathrm{m}^{2}\right)$, d & & & & & & & \\
\hline & TPT $\left(0.75 \mathrm{mg} / \mathrm{m}^{2}\right), \mathrm{dl}-5 \mathrm{q} 2 \mathrm{l}$ & & & & & & & \\
\hline \multirow[t]{3}{*}{ Campos ${ }^{103}$} & PLD $\left(30 \mathrm{mg} / \mathrm{m}^{2}\right), \mathrm{dl}, \mathrm{q} 2 \mathrm{I}$ & ALL 37 & 29.0 & - & 2.5 & 40.0 & 0 & 52.5 \\
\hline & PTX $\left(70 \mathrm{mg} / \mathrm{m}^{2}\right)$, weekly & RES 24 & 17.0 & & & & & \\
\hline & for 18 weeks & SEN I3 & 54.0 & & & & & \\
\hline \multirow[t]{2}{*}{ Katsaros ${ }^{104}$} & PLD $\left(30 \mathrm{mg} / \mathrm{m}^{2}\right), \mathrm{dl}$ & ALL 30 & 37.0 & 5.5 & 0 & 4.0 & 0 & 2.0 \\
\hline & vinorelbine $\left(30 \mathrm{mg} / \mathrm{m}^{2}\right), \mathrm{dl}, \mathrm{q} 2 \mathrm{I}$ & & & & & & & \\
\hline \multirow[t]{3}{*}{ Joly ${ }^{105}$} & PLD $\left(40 \mathrm{mg} / \mathrm{m}^{2}\right), \mathrm{dl}$ & ALL 98 & 28.0 & - & 7.0 & 48.0 & 3.0 & 2.0 \\
\hline & ifosfamide $\left(1700 \mathrm{mg} / \mathrm{m}^{2}\right)$, dl-3 q28 & RES 57 & 19.0 & & & & & \\
\hline & & SEN $4 I^{b}$ & 41.0 & & & & & \\
\hline
\end{tabular}

Abbreviations: GEM, gemcitabine; HFS, hand-foot syndrome; Hgb, anemia; Neu, neutropenia; PFS, progression free survival; RR, response rate; RES, platinum resistant recurrent disease; SEN, platinum sensitive recurrent disease; PLT, platelet toxicity; PTX, paclitaxel;TPT, topotecan; q, every; d, day. aleukopenia; ${ }^{b}$ platinum-sensitive patients are defined as having a 6-12-month platinum free interval. 
which are quite comparable to those reported with other non-platinum combinations. The combination PLD/weekly PTX was well tolerated, as was the PLD/vinorelbine combination. ${ }^{104}$ In contrast, PLD/TPT, even if tested at different doses of the two drugs, was characterized by an unacceptable rate of severe anemia (48\%), leukopenia (70\%), and thrombocytopenia (44\%). ${ }^{102}$

\section{PLD: phase III studies}

Table 9 summarizes the results from randomized trials using PLD alone or in combination in the salvage setting: ${ }^{106-110,112,113,117}$ in the study by O'Byrne et al, ${ }^{106} 214$ recurrent ovarian cancer patients (not defined according to platinum sensitivity) were randomized to either PLD ( $50 \mathrm{mg} / \mathrm{m}^{2}$ every 28 days) or PTX ( $175 \mathrm{mg} / \mathrm{m}^{2}$ every 21 days). Preliminary analysis of the data revealed that there were no significant differences in response rates, PFS, OS, or rate of adverse events. However, since the study was suspended because of poor accrual as paclitaxel became incorporated into first-line chemotherapy, no definitive analysis was carried out.

In the Gordon et al study, ${ }^{107}$ whose updated findings were presented in 2004, ${ }^{108}$ ovarian cancer patients recurring/ progressing after front-line chemotherapy were randomized to receive PLD $\left(50 \mathrm{mg} / \mathrm{m}^{2}\right.$ every 28 days $)$ vs TPT $\left(1.5 \mathrm{mg} / \mathrm{m}^{2}\right.$ days 1 to 5 , every 21 days): in platinum resistant disease

Table 9 Randomized studies with pegylated liposomal doxorubicin (PLD) alone or in combinations in salvage setting

\begin{tabular}{|c|c|c|c|c|c|c|c|c|c|c|}
\hline \multirow[t]{2}{*}{ Author } & \multirow{2}{*}{$\begin{array}{l}\text { Pts } \\
\text { (No.) }\end{array}$} & \multirow[t]{2}{*}{ Drugs/dose } & \multirow[t]{2}{*}{ No. } & \multirow{2}{*}{$\begin{array}{l}\mathbf{R R} \\
(\%)\end{array}$} & \multirow{2}{*}{$\begin{array}{l}\text { PFS } \\
\text { mts }\end{array}$} & \multirow{2}{*}{$\begin{array}{l}\text { OS } \\
\text { mts }\end{array}$} & \multicolumn{4}{|c|}{$\%$ Grade $3 / 4$ toxicity/patient } \\
\hline & & & & & & & Hgb & Neu & PLT & HFS \\
\hline \multirow[t]{2}{*}{ O’Byrne ${ }^{106}$} & $\begin{array}{l}\text { REC } \\
(2 \mid 4)\end{array}$ & $\begin{array}{l}\text { PLD }(50 \text { mg/m²) q28 } \\
\text { vs }\end{array}$ & 107 & 17.8 & 5.4 & 11.4 & - & - & - & - \\
\hline & & PTX $\left(175 \mathrm{mg} / \mathrm{m}^{2}\right) \mathrm{q} 21$ & 107 & 22.4 & 6.0 & 14.0 & & & & \\
\hline \multirow[t]{4}{*}{ Gordon 107,108 } & $\begin{array}{l}\text { RES } \\
(255)\end{array}$ & $\begin{array}{l}\text { PLD }\left(50 \mathrm{mg} / \mathrm{m}^{2}\right) \mathrm{dl}, \mathrm{q} 28 \\
\text { vs }\end{array}$ & 130 & 12.3 & 2.3 & 8.9 & 5 & 12 & 1 & 23 \\
\hline & & TPT $\left(1.5 \mathrm{mg} / \mathrm{m}^{2}\right) \mathrm{dl}-5 \mathrm{q} 2 \mathrm{I}$ & 125 & 6.5 & 3.4 & 10.3 & 28 & 77 & 34 & 0 \\
\hline & $\begin{array}{l}\text { SEN } \\
(219)\end{array}$ & $\begin{array}{l}\text { PLD }\left(50 \mathrm{mg} / \mathrm{m}^{2}\right) \mathrm{dl}, \mathrm{q} 28 \\
\text { vs }\end{array}$ & 109 & 28.4 & 7.2 & 27 & & & & \\
\hline & & TPT $\left(\mathrm{I} .5 \mathrm{mg} / \mathrm{m}^{2}\right) \mathrm{dl}-5, \mathrm{q} 2 \mathrm{I}$ & 110 & 28.8 & $5.8^{*}$ & $17.5^{*}$ & & & & \\
\hline \multirow[t]{2}{*}{ Mutch ${ }^{109}$} & $\begin{array}{l}\mathrm{RES}^{a} \\
(195)\end{array}$ & $\begin{array}{l}\text { PLD }\left(50 \mathrm{mg} / \mathrm{m}^{2}\right) \mathrm{dl}, \mathrm{q} 28 \\
\text { vs }\end{array}$ & 96 & 8.3 & 3.6 & 12.7 & 2.1 & 18.7 & 5.2 & 10.4 \\
\hline & & $\operatorname{GEM}\left(\mathrm{I}, 000 \mathrm{mg} / \mathrm{m}^{2}\right) \mathrm{dI}, 8, \mathrm{q} 2 \mathrm{I}$ & 99 & 6.1 & 3.1 & 13.5 & 3.0 & 38.4 & 6.1 & 0 \\
\hline \multirow[t]{2}{*}{ Ferrandina ${ }^{110}$} & $\begin{array}{l}\text { RES }^{b} \\
(153)\end{array}$ & $\begin{array}{l}\text { PLD }\left(40 \mathrm{mg} / \mathrm{m}^{2}\right) \mathrm{q} 28 \\
\text { vs }\end{array}$ & 76 & 16 & 4.0 & 14 & 5 & 6 & 0 & 5 \\
\hline & & $\operatorname{GEM}\left(1,000 \mathrm{mg} / \mathrm{m}^{2}\right) \mathrm{dl}, 8,15 \mathrm{q} 28$ & 77 & 29 & 5.0 & $12.7^{*}$ & 7 & 23 & 5 & 0 \\
\hline Vergote $^{112}$ & RES $^{c}$ & PLD $\left(50 \mathrm{mg} / \mathrm{m}^{2}\right) \mathrm{dl}, \mathrm{q} 28$ or TPT & 229 & 10.9 & $4.3^{*}$ & $13.5^{*}$ & - & - & - & - \\
\hline \multirow[t]{2}{*}{ ASSIST-I } & $(46 \mathrm{I})$ & $\begin{array}{l}\mathrm{l} .5 \mathrm{mg} / \mathrm{m}^{2} \mathrm{dl}-5 \mathrm{q} 2 \mathrm{l} \\
\text { vs }\end{array}$ & & & & & & & & \\
\hline & & CAN $\left(1,000 \mathrm{mg} / \mathrm{m}^{2}\right) \mathrm{q} 2 \mathrm{I}$ & 232 & 4.3 & 2.3 & 8.5 & - & - & - & - \\
\hline Vergote ${ }^{113}$ & RES $^{c}$ & PLD $\left(50 \mathrm{mg} / \mathrm{m}^{2}\right) \mathrm{dl}$ & 65 & $12.3^{d}$ & $5.6^{d}$ & - & - & - & - & - \\
\hline \multirow[t]{2}{*}{ ASSIST-5 } & $(125)$ & $\begin{array}{l}\text { CAN }\left(1000 \mathrm{mg} / \mathrm{m}^{2}\right) \mathrm{q} 28 \\
\text { vs }\end{array}$ & & & & & & & & \\
\hline & & PLD $\left(50 \mathrm{mg} / \mathrm{m}^{2}\right) \mathrm{dl}, \mathrm{q} 28$ & 60 & 8.3 & 3.7 & - & - & - & - & - \\
\hline Monk $^{117}$ & ALL & PLD $\left(30 \mathrm{mg} / \mathrm{m}^{2}\right) \mathrm{dl}$ & 335 & $28.0 *$ & $7.3^{*}$ & $20.5^{e}$ & 14.0 & 63.0 & 18.0 & 4.0 \\
\hline \multirow[t]{4}{*}{ OVA-30I } & $(672)$ & $\begin{array}{l}\text { TRAB }\left(1.1 \mathrm{mg} / \mathrm{m}^{2}\right) \mathrm{dl}, \mathrm{q} 2 \mathrm{I} \\
\text { vs }\end{array}$ & & & & & & & & \\
\hline & & PLD $\left(50 \mathrm{mg} / \mathrm{m}^{2}\right) \mathrm{q} 28$ & 337 & 19.0 & 5.9 & 19.4 & 6.0 & 22.0 & 2.0 & 20.0 \\
\hline & $\begin{array}{l}\text { SEN } \\
(430)\end{array}$ & $\begin{array}{l}\operatorname{PLD}\left(30 \mathrm{mg} / \mathrm{m}^{2}\right) \mathrm{dl} \\
\operatorname{TRAB}\left(I . \mathrm{mg} / \mathrm{m}^{2}\right) \mathrm{dl}, \mathrm{q} 2 \mathrm{I} \\
\text { vs }\end{array}$ & - & $35^{*}$ & $9.2 *$ & - & - & - & - & - \\
\hline & & PLD $\left(50 \mathrm{mg} / \mathrm{m}^{2}\right) \mathrm{q} 28$ & - & 23 & 7.5 & - & - & - & - & - \\
\hline
\end{tabular}

Abbreviations: CAN, canfosfamide; GEM, gemcitabine; HFS, hand-foot syndrome; Hgb, anemia; Neu, neutropenia; OS, overall survival; PFS, progression-free survival; PLT, platelet toxicity; PTX, paclitaxel; REC, not otherwise specified recurrent disease; RES, platinum-resistant recurrent disease; RR, response rate; SEN, platinum-sensitive recurrent disease;TRAB, trabectedin; q, every; d, day.

*statistically significant.

${ }^{a}$ up to 2 prior regimens allowed; ${ }^{b}$ platinum resistance = recurrence/progression within 12 months from primary chemotherapy; ${ }^{c}$ patients progressed on 2 nd line treatment; ${ }^{\text {in }}$ the subgroup of platinum refractory/resistant $(n=75)$, the combination achieved a high response rate $(I 5.0 \%$ vs $5.7 \%)$ and a longer PFS $($ median $=5.6$ months vs 2.9 months) $(H R=0.55 ; P=0.042)$; ${ }^{~}$ results from interim analysis. 
$(\mathrm{n}=255)$ no significant difference was seen in response rate, PFS, or OS between the two treatment arms, while in platinum-sensitive patients $(\mathrm{n}=219)$, median PFS and OS were significantly prolonged in PLD- vs TPT-treated patients $(P$ value $=0.037$, and $P$ value $=0.008$, respectively $)$. More mature survival analysis confirmed the long-term advantage for platinum-sensitive patients receiving PLD vs TPT (median OS $=27$ months vs 17.5 months, hazard ratio $[\mathrm{HR}]=1.432, P$ value $=0.017) .{ }^{108}$ Moreover, for partially platinum-sensitive disease $(\mathrm{n}=122)$, the HR favored PLD vs TPT $(\mathrm{HR}=1.58, P$ value $=0.021)$.

The toxicity profiles of the two drugs were completely different, grade $3 / 4$ hematological toxicity occurring more frequently and more severely in TPT vs PLD: in particular, severe neutropenia was documented in $77 \%$ of TPT- vs $12 \%$ of PLD-treated patients $(P<0001)$, and thrombocytopenia was found in $34 \%$ of TPT vs $1 \%$ of PLD cases $(P<0.001)$. No case of severe HFS was documented in the TPT arm while it was registered in 23\% of PLD-treated patients $(P<$ 0.001). Although compliance to fulfil the EORTC-QLQ-C30 questionnaire was poor, thus leaving at 12 weeks of treatment only 200 patients available for comparison, there were no differences in terms of functional and symptom scale QoL scores between the two arms.

Two more recent phase III trials commpared PLD with GEM in recurrent platinum-resistant ovarian cancer patients: Mutch et a ${ }^{109}$ studied 195 cases experiencing progressive disease within 6 months of completing first-line platinumbased therapy: patients were randomly assigned to either PLD (50 $\mathrm{mg} / \mathrm{m}^{2}$ every 28 days) or GEM $\left(1000 \mathrm{mg} / \mathrm{m}^{2}\right.$, days 1,8 , every 21 days) until progression or undue toxicity. Almost $36 \%$ of cases in the overall series had already received 2 prior regimens; moreover, response was assessed on the basis of CA15 levels only, in approximately $36 \%$ of cases. There was no difference in the response rate between the two treatment arms; median PFS was 3.6 and 3.1 months in PLD vs GEM-treated arms, respectively, while median OS was 12.7 vs 13.5 months: none of the survival end-points showed a statistically significant difference between the two treatment groups.

In contrast to the study of Mutch et al, ${ }^{109}$ the MITO-3 trial on behalf of the Multicenter Italian Trials in Ovarian cancer (MITO) Group was conducted on patients who recurred/ progressed within 12 months from the completion of primary treatment and had received only one platinum/paclitaxel regimen; ${ }^{110}$ the study included 153 cases ( 86 patients with a PFI $<6$ months and 67 patients with a PFI within 7 to 12 months) who were randomized to PLD $\left(40 \mathrm{mg} / \mathrm{m}^{2}\right.$, every
28 days) vs GEM $\left(1,000 \mathrm{mg} / \mathrm{m}^{2}, \mathrm{~d} 1,8,15\right.$, every 28 days $)$. In the whole series the response rate was $16 \%$ in PLD vs $29 \%$ in GEM treated patients $(P$ value $=0.066)$. No statistically significant difference was documented between the two treatment arms in terms of PFS; however, a more favorable OS was registered in the PLD- vs the GEM-treated arm (median OS = 14 months vs 12.7 months, respectively; $P$ value $=0.048)$. With the limits inherent in the small sample series, the survival advantage reported with PLD over GEM was maintained in the subgroup of partially sensitive patients $(P$ value $=0.016)$

Higher global QoL scores especially for physical and emotional findings and fatigue were found in PLD-treated patients at the first and second post-baseline assessments, and this is likely to reflect the profile of toxicity: indeed, hematological toxicity was negligible, with only $6 \%$ of grade $3 / 4$ neutropenia compared to $23 \%$ in the GEM arm. Moreover, severe HFS was documented in only $5 \%$ of cases, in line with the results of previously reported phase II studies (see Table 6).

Very recently, the activity of canfosfamide (CAN) $\left(\right.$ Telcyta $^{\circledR}$ ), a glutathione analog prodrug which, upon activation by glutathione S-transferase P1-1, is able to induce cellular apoptosis, ${ }^{111}$ has been tested with a control arm represented by PLD or TPT in platinum-resistant recurrent ovarian cancer patients who had already progressed on second-line treatment with PLD or TPT ${ }^{112}$ (ASSIST-1, NCT00057720). Patients $(\mathrm{n}=461)$ were randomized to receive PLD ( $50 \mathrm{mg} / \mathrm{m}^{2}$ every 28 days $)$ or TPT $\left(1.5 \mathrm{mg} / \mathrm{m}^{2}\right.$, days 1 to 5 , every 21 days) vs CAN $\left(1000 \mathrm{mg} / \mathrm{m}^{2}\right.$ every 21 days). The overall response rate was higher in the control arm vs CAN ( $10.9 \%$ vs $4.3 \%$, respectively), as was also median PFS (4.3 months vs 2.3 months, $P$ value $=0.01$ ). An overall survival advantage favoring the control arm vs CAN was also documented; in particular, median OS was 13.5 months in the control (14.2 months in PLD, 10.8 months in TPT) vs 8.5 months in the CAN arm $(P<0.01)$. Based on these results, which basically represent the first evidence from a randomized study of prolongation of OS with thirdline treatment, a phase III trial (ASSIST-5, NCT00350948) comparing the combination PLD/CAN vs PLD alone had been planned based on the demonstration that PLD might favor glutathione S-transferase expression, thus potentially increasing cancer cell susceptibility to CAN: patients were randomized to receive PLD $\left(50 \mathrm{mg} / \mathrm{m}^{2}\right)$ plus CAN $\left(1000 \mathrm{mg} / \mathrm{m}^{2}\right)$ every 28 days, vs PLD $\left(50 \mathrm{mg} / \mathrm{m}^{2}\right.$ every 28 days). The primary end-point of the study was originally represented by OS and the planned sample size 
Table 10 Randomized studies with pegylated liposomal doxorubicin (PLD) in combination with platinum in salvage setting

\begin{tabular}{|c|c|c|c|c|c|c|c|c|c|c|}
\hline \multirow[t]{2}{*}{ Author } & \multirow[t]{2}{*}{ Pts } & \multirow[t]{2}{*}{ Drugs/dose } & \multirow[t]{2}{*}{ No. pts } & \multirow{2}{*}{$\begin{array}{l}\text { RR } \\
\text { (\%) }\end{array}$} & \multirow{2}{*}{$\begin{array}{l}\text { PFS } \\
\text { mts }\end{array}$} & \multirow{2}{*}{$\begin{array}{l}\text { OS } \\
\text { mts }\end{array}$} & \multicolumn{4}{|c|}{$\%$ Grade $3 / 4$ toxicity/patient } \\
\hline & & & & & & & Hgb & Neu & PLT & HFS \\
\hline Alberts $119, \mathrm{a}$ & SEN & PLD $(30$ mg/m²) dl & 31 & 52 & $12^{*}$ & $26^{*}$ & 16 & 48.0 & 39.0 & 3.0 \\
\hline \multirow[t]{2}{*}{ SWOG SO200 } & $6-24 \mathrm{mts}$ & $\begin{array}{l}\text { JM8 (AUC 5) dl, q28 } \\
\text { vs }\end{array}$ & & & & & & & & \\
\hline & & JM8 (AUC 5) dl, q28 & 30 & 29 & 8 & 18 & 0 & 3.0 & 0 & 0 \\
\hline Markman $^{120}$ & SEN & $\operatorname{PLD}(30$ mg/m²) dl & 31 & $59 *$ & $12 *$ & 31 & - & - & - & - \\
\hline \multirow[t]{2}{*}{ SWOG SO200 } & $6-24 \mathrm{mts}$ & $\begin{array}{l}\text { JM8 (AUC 5) dl, q28 } \\
\text { vs }\end{array}$ & & & & & & & & \\
\hline & & JM8 (AUC 5) dl, q28 & 30 & 28 & 8 & 18 & - & - & - & - \\
\hline \multirow[t]{2}{*}{ Linardou ${ }^{121, b}$} & $\begin{array}{l}\text { SEN } \\
>6 \mathrm{mts}\end{array}$ & $\begin{array}{l}\text { PLD }\left(45 \mathrm{mg} / \mathrm{m}^{2}\right) \mathrm{dl} \\
\text { JM8 (AUC 5) dl, q28 } \\
\text { vs }\end{array}$ & 93 & 51 & 11.7 & 24.4 & - & 35.0 & 12.0 & 0 \\
\hline & & $\begin{array}{l}\text { PTX }\left(175 \mathrm{mg} / \mathrm{m}^{2}\right) \mathrm{dl} \\
\text { JM8 (AUC 5) dl, q2। }\end{array}$ & 96 & 58 & 10.8 & 30.4 & - & 30.0 & $12.0 *$ & - \\
\hline \multirow[t]{2}{*}{$\begin{array}{l}\text { Pujade-Lauraine }{ }^{122} \\
\text { CALYPSO } \\
\text { (EORTC 5505I) }\end{array}$} & $\begin{array}{l}\text { SEN } \\
>6 \mathrm{mts}\end{array}$ & $\begin{array}{l}\text { PLD }\left(30 \mathrm{mg} / \mathrm{m}^{2}\right) \mathrm{dl} \\
\text { JM8 (AUC 5) dl, q28 } \\
\text { vs }\end{array}$ & 467 & - & $11.3^{*}$ & $-^{c}$ & - & 35.0 & 16.0 & 1.0 \\
\hline & & $\begin{array}{l}\text { PTX }\left(I 75 \mathrm{mg} / \mathrm{m}^{2}\right) \mathrm{dl} \\
\text { JM8 (AUC 5) dl, q2I }\end{array}$ & 509 & - & 9.4 & - & - & 46.0 & 6.0 & 1.0 \\
\hline
\end{tabular}

*statistically significant.

${ }^{a}$ prematurely closed for slow accrual; ${ }^{b}$ randomized phase II study; 'too early to be reported.

Abbreviations: HFS, hand-foot syndrome; Hgb, anemia; JM8, carboplatin; Neu, neutropenia, PFS, progression-free survival; PLT, platelet toxicity; PTX, paclitaxel; RR, response rate; RES, platinum-resistant recurrent disease; SEN, platinum-sensitive recurrent disease; q, every; d, day.

corresponded to 244 platinum resistant recurrent OvCa patients who had already been administered at least 2 previous lines of chemotherapy. However, the study was temporarily suspended while waiting for the data from the ASSIST-1 study, and, at the time enrolment was re-started, the primary end-point had been replaced by PFS, while 35 out of 125 patients enrolled had not received the planned drug. ${ }^{113}$ In the intention to treat analysis, no difference emerged between the two treatment arms in terms of response rate and PFS; however, when considering the subgroup of platinum-refractory and primary platinumresistant patients, a statistically significant advantage in favor of the combination was observed in terms of response rate $(15.0 \%$ vs 5.7\%) and PFS (median 5.6 months vs 2.9 months, $\mathrm{HR}=0.55, P$ value $=0.042$ ). A trend for a longer OS was also observed in the combination vs single agent arm (median OS = 11.8 months vs 7.8 months), although statistical significance was not reached. While the hematological toxicity was generally higher in the combination arm vs PLD alone, the rate of grade $2 / 3$ HFS was lower in PLD/CAN than PLD alone (9\% vs $21 \%$, respectively), although the reasons for the protection conferred by the combination remain unclear. These data are the first to report a potential advantage related to the use of a doublet in the poor-prognosis subset of platinum-resistant OvCa patients, and need to be confirmed in the final analysis.
At this time, available data support the phase II-derived suggestions that in platinum-resistant disease none of the currently most frequently used drugs, such as PLD, GEM, or TPT, shows superiority over the others in terms of response rate and survival; in this context the 3 -week schedule of administration of PLD at $40 \mathrm{mg} / \mathrm{m}^{2}$ seems to offer the most favorable toxicity profile, which is likely to sustain the achievement of better QoL scores, at least in comparison to GEM. ${ }^{110}$

Among the most intriguing novel drugs, trabectedin (TRAB) (ET743; Yondelis $\left.{ }^{\circledR}\right)$, the marine compound derived from Ecteinascidia turbinata, has become relevant for treatment of sarcomas and other solid tumors. ${ }^{114}$ TRAB has a unique mechanism of action, in that, unlike most other agents, it binds to the minor groove of DNA thus affecting a variety of transcription factors, cell proliferation, and the nucleotide excision repair system. In addition, TRAB inhibits the MDR-1 gene coding for the protein responsible for chemoresistance. ${ }^{114}$ Based on safety and efficacy results from phase I/II studies in several advanced malignancies, including resistant and particularly platinum-sensitive recurrent $\mathrm{OvCa}$ patients, ${ }^{115,116}$ a phase III trial (OVA-301, NCT00113607) has been planned to compare PLD $50 \mathrm{mg} / \mathrm{m}^{2}$ every 28 days with the combination PLD $30 \mathrm{mg} / \mathrm{m}^{2}$ and TRAB $1.1 \mathrm{mg} / \mathrm{m}^{2}$ every 21 days, in ovarian, peritoneal, and tubal cancer recurring/progressing after first-line chemotherapy, ${ }^{117}$ with 
the exclusion of refractory cases; patients were stratified according to ECOG PS (0-1 vs 2 ), and platinum sensitivity (PFI $<6$ months vs PFI $\geq 6$ months). Originally, the primary end-point was the OS but it was later amended to PFS at the end of 2006. Secondary end-points included OS, response rates, safety, and pharmacokinetics. Overall, 672 patients were enrolled (337 allocated to PLD/TRAB vs 335 allocated to PLD). In the whole series the response rate as assessed by independent radiology review by Response Evaluation Criteria In Solid Tumors (RECIST) was significantly higher in PLD/TRAB than PLD alone group, as was also median PFS $(\mathrm{HR}=0.79, P$ value $=0.019)$. However, in platinumresistant cases $(n=242)$, no difference was observed in the combination vs PLD alone in terms of response rate $(13.4 \%$ vs $12.2 \%$, respectively), and PFS, while a clear advantage favoring the combination compared to single-agent PLD was evident in platinum-sensitive disease $(\mathrm{n}=430)$ (response rate $35.3 \%$ vs $22.6 \%, P=0.0042$; median PFS 9.2 months vs 7.5 months; HR $=0.73, P=0.017$ ). In the context of platinum-sensitive disease, these findings were also evident in the subset of partially platinum-sensitive disease with median PFS of 7.4 vs 5.5 months in PLD/TRAB vs PLD $\operatorname{arm}(\mathrm{HR}=0.65, P=0.0152)$.

Grade 3/4 anemia, neutropenia and thrombocytopenia were documented in $14 \%, 63 \%$, and $18 \%$ of PLD/TRAB cases, and were significantly more frequent compared to PLD alone. Among non-hematological toxicities, grade $3 / 4$ elevation of sGOT, and sGPT was reported in $38 \%$ of cases: they were described as of short duration, and of decreased magnitude with succeeding cycles. On the other hand, HFS was documented in $4 \%$ of the PLD/TRAB arm compared to $20 \%$ in the PLD alone arm. In spite of the increased hematological toxicity in the PLD/TRAB group there was no deterioration of QoL/patient reported outcome (PRO), QLQ-C30 and OV28 and EQ-5D scales. ${ }^{118}$ Based on these results, which support the PLD/TRAB combination as the most effective non-platinum based combination in platinum-sensitive disease, the combination PLD $\left(30 \mathrm{mg} / \mathrm{m}^{2}\right)$ and TRAB $\left(1.1 \mathrm{mg} / \mathrm{m}^{2}\right)$, every 3 weeks, has been recently approved by the EMEA (September 2009), and is currently submitted for FDA approval for treatment of patients with relapsed platinum-sensitive $\mathrm{OvCa}$.

Among platinum combinations, which are well established to be superior to platinum agents alone in the recurrent setting, PLD/JM8 regimens seem to offer the most effective therapeutic index compared to combinations with taxanes and gemcitabine, ${ }^{81,82}$ as also suggested by phase II studies. Indeed, the SWOG SO200 trial ${ }^{119}$ compared
PLD/JM8 combination to JM8 alone, but was prematurely stopped because of slow accrual probably related to the introduction of PTX as the JM8 partner in the salvage setting; however, final re-analysis of survival analysis has been very recently published, ${ }^{120}$ showing that with longer follow up and additional events, a statistically significant improvement of PFS with the combination has been registered, although the previously reported more favorable OS could no longer be detected. Interestingly, for unknown reasons, the association of PLD with JM8 drastically reduced the rate of hypersensitivity reactions compared to JM8 alone ( $9 \%$ vs $0 \%, P=0.0008)$.

The other randomized trials tested PLD/JM8 regimen against PTX/JM8 doublet: in particular, the phase II randomized study by Linardou et $\mathrm{al}^{121}$ documented no difference between the two arms in terms of response rate and PFS, probably because of the small sample size, while confirming the very favorable toxicity profile for the combination, which resulted in a lower rate of severe thrombocytopenia and, more importantly, in no case of severe neurotoxicity.

At the 2009 ASCO meeting the Gynecologic Cancer Intergroup presented the preliminary results of CALYPSO trial (EORTC 55051), ${ }^{122}$ a randomized phase III study which accrued $976 \mathrm{OvCa}$ patients recurring after 6 months after their first- or second-line platinum based therapy. Patients were randomized: the control group received JM8 AUC 5 and PTX $175 \mathrm{mg} / \mathrm{m}^{2}$ every 21 days and the experimental group received JM8 AUC 5 and PLD $30 \mathrm{mg} / \mathrm{m}^{2}$ every 28 days. The trial showed a statistically significant superiority of PLD/JM8 over PTX/JM8 combination in terms of PFS. Moreover, the superiority of PLD/JM8 was also confirmed in the subset of partially platinum-sensitive disease. ${ }^{123}$ With a median follow up of 21 months and 308 events, data on OS were be reported early. While grade $\geq 2$ HFS was documented in $13 \%$ of the PLD/JM8 vs $2 \%$ of the PTX/JM8 arm, lower rates of grade $2 / 3$ neurotoxicity were reported in the experimental than in the standard arm ( $5 \%$ vs $28 \%$, respectively). Interestingly, severe hypersensitivity reactions occurred less frequently in PLD/JM8 than in PTX/JM8 group (2\% vs 9\%).

While waiting for the mature OS data from the CALYPSO trial, it can be reasonably stated that the PLD/ JM8 combination represents a valid alternative to other platinum-based regimens in recurrent platinum-sensitive OvCa especially for patients whose QoL is recognized to be heavily compromised by alopecia, or who had experienced or had not yet been rescued from taxane-induced neurotoxicity. 
Attempts to include PLD in front-line treatment have also been attempted: in particular, with the aim of improving PTX/JM8 efficacy, sequential doublets or triplet combinations including PLD have been investigated based also on the very favorable and not overlapping toxicity profile. The use of 4 cycles of standard PTX/JM8 (175 mg/m², AUC 6, every 21 days) followed by 4 cycles of PLD/JM8 (40 mg/m², AUC 6, every 21 days) has been first investigated by Potamianou et $\mathrm{al}^{124}$ in a phase II study including 41 patients. At the end of the 8 courses the response rate was $66 \%$, and median PFS was 20 months. Toxicity mainly consisted of neutropenia, which occurred in $48.7 \%$ of patients at the end of JM8/PTX and $63.8 \%$ at the end of PLD/JM8 treatment. There was no undue or unexpected non-hematological toxicity, but grade 2 and 3 neurotoxicity after PTX/JM8 was registered in 9\% and $34.1 \%$ of patients, respectively. The potential efficacy of triplets and sequential doublets has been also investigated in the GOG182/ICON5 randomized trial, ${ }^{125}$ which represents the largest cooperative effort attempted worldwide by the Gynecologic Oncology Group in the US, and the Medical Research Council in the UK on behalf of the International Collaborative Ovarian Neoplasm (ICON) Group. The GOG182/ICON5 trial enrolled 4312 stage III/IV patients who were randomized to 5 arms including the standard treatment 1) JM8 AUC 6, PTX $175 \mathrm{mg} / \mathrm{m}^{2}$ every 21 days, 8 cycles, vs 2 triplets; 2) JM8 AUC 5, PTX $175 \mathrm{mg} / \mathrm{m}^{2}$, GEM $800 \mathrm{mg} / \mathrm{m}^{2}$ days 1, 8, every 21 days, 8 cycles; 3) JM8 AUC 5, PTX $175 \mathrm{mg} / \mathrm{m}^{2}$, every 21 days plus PLD $30 \mathrm{mg} / \mathrm{m}^{2}$, every other cycle, 8 cycles, or 2 sequential doublets: 4) JM8 AUC 6, TPT $1.25 \mathrm{mg} / \mathrm{m}^{2}$ days 1 to 3,4 cycles, followed by JM8 AUC 6, PTX 175 mg/m², 4 cycles; 5) JM8 AUC 6, GEM $800 \mathrm{mg} / \mathrm{m}^{2}$, days 1,8 every 21 days, 4 cycles followed by JM8 AUC 6, PTX 175 mg/m², 4 cycles.

Despite the documentation of increased hematological and non-hematological toxicity in the triplet regimens, there was no PFS or OS advantage with sequential doublets or with triplets compared with the control arm.

In the front-line setting, mature results from the MITO2 (NCT00326456) ${ }^{126,127}$ trial are eagerly awaited; this study, which first investigated the combination PLD/JM8 (30 $\mathrm{mg} / \mathrm{m}^{2}, \mathrm{AUC}=5$, every 21 days) vs the standard treatment, has randomized 820 stage IC/IV ovarian cancer patients since January 2003 to November 2007. The primary objective was PFS, while secondary objectives were OS, response rate, toxicity and QoL. Data presented at the 2009 ASCO meeting documented the equivalence of the two treatment arms in terms of response rate $(59.0 \%$ in the standard vs $57.0 \%$ in the experimental arm, $P=0.70) .{ }^{128}$ As of March 2009, with a median follow up of 35 months, 530 events for PFS and 269 deaths were documented; therefore survival data cannot be considered mature enough for final analysis, which will be hopefully available in 2010 . As expected, the pattern of toxicity differed between the two groups: severe anemia and thrombocytopenia were more frequently detected in PLD/JM8 vs the standard arm $(10 \%$ vs $4 \%, P<0.001$, for anemia) (16\% vs $2 \%, P<0.001$, for thrombocytopenia). On the other hand, grade $\geq 3$ neurotoxicity was registered in $3 \%$ of standard vs $0.3 \%$ in the experimental treatment $(P=0.004)$. Finally, alopecia (any grade) occurred in $63 \%$ of cases allocated to the standard vs $14 \%$ allocated the experimental arm $(P<0.001)$.

\section{PLD and target-based agents}

Given the relevance of PLD alone or in combination with platinum as well as non-platinum agents in almost all clinical settings of ovarian cancer, it is not surprising that attempts are ongoing to study combinations of this drug with targetbased agents: the rationale of this approach is represented by the enormous potential inherent in classes of drugs with a different mechanism of action. Moreover, the availability of target-based agents at an advanced stage of clinical development, and therefore with a well known spectrum of activity and toxicity, has fuelled great enthusiasm for exploring their association with PLD. Among the most appealing classes of biological drugs, the angiogenesis inhibitors seem to be the most promising: in particular, several phase II trials have shown the activity of bevacizumab (BEV) (Avastin ${ }^{\circledR}$ ), the monoclonal antibody against vascular endothelial growth factor (VEGF), in platinum-resistant and -sensitive disease. ${ }^{129}$ Preliminary results from an ongoing phase II study have been recently presented at the 2009 ASCO meeting, on the PLD/BEV combination in second-line treatment of OvCa patients with a PFI $\leq 6$ months and with $<3$ previous regimens. ${ }^{130}$ The study was started in 2007 and aimed at recruiting 48 patients. PLD (30 mg/m² every 21 days) was administered alone at the first cycle, and then with BEV (15 mg/kg every 21 days) for the following 6 cycles or until progression. In the 21 patients available for analysis, response was documented in $14.3 \%$ of cases according to the RECIST criteria, and in 8 out of 14 cases (57.1\%) who had elevated Ca125 levels at enrolment. In $62 \%$ of cases PFS duration exceeded 18 weeks. Interestingly, the pharmacokinetics measures obtained after 1 hour, and at day 7 and day 21 of the first 2 cycles did not show any BEVinduced modification of PLD pharmacokinetics. Grade 3 HFS was registered in 5\% of cases, and PLD dose reduction 
was required in 33\% of cases, while grade 3 hypertension and $\mathrm{BEV}$ reduction $>10 \%$ was reported in $15 \%$ of cases. With the aim of reducing the rate/severity of side effects, a weekly regimen of PLD/BEV (PLD $10 \mathrm{mg} / \mathrm{m}^{2}$ and BEV $2 \mathrm{mg} / \mathrm{kg}$ days $1,8,15$, every 28 days, for at least 3 cycles) was investigated in 30 recurrent $\mathrm{OvCa}$ patients who had been heavily pre-treated. ${ }^{131}$ According to the Gynecologic Cancer Intergroup criteria, an overall response rate of $45 \%$ was achieved in 26 evaluable patients with a clinical benefit in $75 \%$ of cases. On the basis of the RECIST criteria, response was achieved in $38.4 \%$ of cases with disease stabilization in $34.6 \%$. No severe hematological toxicity was observed, and the only cases experiencing gastrointestinal perforation were treated conservatively. HFS was documented in $13.6 \%$ and required treatment in only one case. Overall, the weekly regimen seems well tolerated although the potential cumulative cardiovascular side effects of the two drugs need to be explored in a larger series. A large phase II randomized study (AURELIA, NCT00976911) is ongoing, which recruits patients with recurrent platinum-resistant ovarian, fallopian tube and peritoneal cancer, who are randomized to standard treatment (PTX, or TPT, or PLD $40 \mathrm{mg} / \mathrm{m}^{2}$ every 28 days) vs the experimental arm in which BEV $10 \mathrm{mg} / \mathrm{m}^{2}$ bi-weekly or $15 \mathrm{mg} / \mathrm{m}^{2}$ every 21 days is added to the same drugs. Among novel VEGFR kinase inhibitors, vandetanib is currently being investigated in combination with PLD in recurrent OvCa (NCT00862836).

The interest in other angiogenesis inhibitors is shown by the efforts to study molecules acting on different targets, such as volociximab (VOL). This is a chimeric monoclonal antibody able to directly target $\alpha 5 / \beta 1$ integrin, a protein characterizing the activated endothelial cells, thus preventing its interaction with the extracellular fibronectin and disrupting tumor neoangiogenesis. ${ }^{132}$ A phase II study by Vergote et $\mathrm{al}^{133}$ has been carried out in recurrent OvCa patients who had already been administered up to 2 lines of chemotherapy; patients received PLD $40 \mathrm{mg} / \mathrm{m}^{2}$ every 28 days $(\mathrm{n}=15)$, or PLD $40 \mathrm{mg} / \mathrm{m}^{2}$, every 28 days and VOL $15 \mathrm{mg} / \mathrm{m}^{2}$ biweekly $(\mathrm{n}=15)$ or PLD $40 \mathrm{mg} / \mathrm{m}^{2}$ every 28 days and VOL $15 \mathrm{mg} / \mathrm{m}^{2}$ weekly $(n=15)$. According to the PFS duration documented in each arm, an increasing number of cases would be enrolled in more favorable arms. 66 patients were enrolled in the first arm while 34 and 27 patients were allocated to the remaining groups. Median PFS was 27.5 weeks in the first arm, 18 weeks in the second and 31.6 weeks in the third, thus suggesting no superiority of the combination vs PLD alone. Severe side effects have been documented in $<5 \%$ of cases in each treatment arm and, interestingly, in this study also, the addition of the target-based agent did not seem to alter PLD pharmacokinetics.

A summary of the ongoing trials investigating the combination of PLD with other growth factor receptor inhibitors such as IMC-3G3, an inhibitor of PDGF-R (NCT00913835), panitumumab (an EGF-R blocker) (NCT00861120), and pazopanib (which interferes with VEGF-R1,2,3 kinase, PDGF-R and c-kit oncogene product) (NCT01035658) can be found at the www.clinicaltrials.gov.

Besides the attempts to study the association of PLD with drugs interfering with the angiogenic and growth factor driven mitogenic processes, other novel biological targets crucial for cancer cell biology have been considered for designing PLD/target based therapy: for instance farletuzumab (MORAB-003), an inhibitor of folate receptor- $\alpha$, is under investigation combined with PLD and JM8 in recurrent platinum-sensitive recurrent OvCa (NCT01004380). Moreover, based on preclinical studies and encouraging phase I data showing the absence of any interference of bortezomib (BOR; Velcade ${ }^{\circledR}$ ), a proteasome inhibitor, with PLD pharmacokinetics, ${ }^{134}$ preliminary results of a phase II study combining the two drugs were presented at the 2008 ASCO meeting; ${ }^{135}$ recurrent platinum-resistant $(n=15)$, and -sensitive $(\mathrm{n}=15)$ OvCa patients were administered PLD $30 \mathrm{mg} / \mathrm{m}^{2}$ and BOR $1.3 \mathrm{mg} / \mathrm{m}^{2}$ days 1, 4, 8, 11 every 21 days. Responses were seen only in the platinum-sensitive disease group which proceeded to the second step of enrolment.

Although all these data are very preliminary, it seems that quite tolerable combinations of PLD with targetbased agents can be used without interfering with PLD pharmacokinetics.

\section{PLD: toxicity issues}

The very favorable PLD toxicity profile is widely recognized as the advantage of this drug, which does not accumulate in normal tissues and especially in cardiac muscle, thus eliminating the cardiotoxicity commonly associated with conventional doxorubicin administration. ${ }^{136}$ However, some adverse side effects have to be taken into account: acute hypersensitivity reaction, characterized by flushing, headache, facial edema, back pain, rigors, dyspnea, hypotension and chest/throat tightness can occur during drug infusion (and differently from hypersensitivity reactions with other drugs which generally are documented after a previous exposure), they can be registered even during the first administration. PLD-related reactions are seen in about $6.8 \%$ of patients; however, if they are not documented initially, they rarely occur in subsequent cycles. ${ }^{14}$ Moreover, hypersensitivity 
reactions seem to depend on the infusion rate, and can therefore be prevented, in principle, by administering the drug at an initial rate of $1 \mathrm{mg} / \mathrm{min}$. Muco-cutaneous toxicity is the most frequent PLD-related side effect, and represents the most important dose-limiting toxicity. ${ }^{19}$ In particular, palmar-plantar erythrodysesthesia, also known as HFS and originally described as associated with 5-fluorouracil infusion, represents a distinctive toxic reaction to PLD administration. Pathogenesis remains unclear, although it is generally accepted that the prolonged accumulation of PLD in areas where subclinical trauma occurs (due to friction, tight-fitting clothing or shoes, repeated skin pressure or chemical insults), leading to inflammation and subsequent altered vascular permeability, might play a relevant role. ${ }^{137}$ It has been suggested that PLD transport by sweat could lead to an easy localization of the drug into the stratum corneum where free radicals are produced and HFS can be induced. ${ }^{138}$

HFS is characterized by paresthesia of the outer extremities occurring 2 to 12 days after chemotherapy administration, and is followed 3 to 4 days later by patch erythema, edema, and desquamation of hands and soles. The natural history of HFS is often self-limiting with resolution within 1 to 5 weeks from stopping treatment. However, some cases develop blistering and ulceration which can limit daily functions and reduce patient quality of life. Recently, the investigation of factors favoring the occurrence of HFS during PLD treatment has been carried out in a very large series of recurrent ovarian, peritoneal and fallopian tube cancer patients: the number of PLD cycles and doses $\geq 50 \mathrm{mg} / \mathrm{m}^{2}$ as well as the concomitant occurrence of neutropenia, and peripheral neuropathy were predisposing factors for HFS. ${ }^{101}$ Moreover, the incidence of HFS was higher in patients receiving $>3$ lines of previous chemotherapy lines regardless of chemotherapeutic agents used. Surprisingly, the proportion of cases who suffered PPE was higher in cases of cooling mechanism adoption, ${ }^{101}$ while patient age and mean body mass index did not affect HFS development, confirming previously published results. ${ }^{139}$ Besides the cumulative dose, the schedule of administration also seems to be an important risk factor: in particular, it has been suggested that the 3-week schedule may coincide with the interval of epidermal turnover, a phenomenon that would thus emphasize the potential PLD-induced keratinocyte damage. ${ }^{140}$ Patient education to avoid risk factors by preventing mechanical, physical, or chemical skin insults, and to recognize early the initial signs/symptoms of skin toxicity is relevant. More specifically, the use of ice pack cooling of hands and feet associated with consumption of iced liquids during chemotherapy administration has been empirically explored, ${ }^{141}$ as well as the administration of corticosteroids, pyridoxine supplement, topical application of dimethylsulfoxide, and emollient or moisturizing lotions which are often used in clinical practice. ${ }^{142}$ However, with the exception of pyridoxine supplement which has been recently tested in a phase III study and shown not to confer any advantage compared to placebo in terms of HFS prevention, ${ }^{143}$ the true efficacy of the other approaches has not been proven in prospective trials. Apart from the studies suggesting that the bi-weekly schedule, or the 4-weekly administration of PLD at doses of $40 \mathrm{mg} / \mathrm{m}^{2}$ are associated with negligible if any severe HFS (see Table 6), a randomized phase II trial in metastatic breast cancer has also shown that by reducing PLD dose intensity to $10 \mathrm{mg} / \mathrm{m}^{2} /$ week, HFS tends to be mild or modest in the vast majority of cases. ${ }^{144}$ Recently, an international panel of experts was convened to develop recommendations for management of PLD-associated HFS according to the grade of symptoms and clinical findings; ${ }^{145}$ however, phase III trials are urgently needed to support the rigorous adoption of any of these previously cited interventions.

\section{Conclusions}

The pegylated liposomal formulation of doxorubicin, because of its unique and favorable toxicity profile, has greatly expanded the clinical applications of the parent compound: indeed, whether used alone or in combination with nonplatinum and platinum agents, PLD has been introduced in the management of almost all clinical settings in $\mathrm{OvCa}$ patients.

In particular, results from phase II and phase III randomized trials have led to FDA approval of PLD in the salvage treatment of recurrent disease; moreover, the upcoming mature results of the CALYPSO trial suggest that PLD/ carboplatin combination is a very valid option in recurrent platinum-sensitive disease especially in patients who had experienced or had not yet been rescued from taxane-induced neurotoxicity or just refuse to tolerate alopecia. The MITO-2 final results might lead to the replacement of paclitaxel as the carboplatin partner in front-line treatment, or at least provide a useful alternative to carboplatin/paclitaxel depending on patient performance status and preference. Meanwhile efforts will continue in combining PLD with target-based agents which have already shown preliminary promising activity in ovarian malignancies, and do not seem to alter the unique and advantageous pharmacokinetics of PLD.

\section{Disclosures}

The authors declare no conflicts of interest. 


\section{References}

1. Jemal A, Siegel R, Ward E, Hao Y, Xu J, Thun MJ. Cancer statistics, 2009. CA Cancer J Clin. 2009;59:225-249.

2. Eisenkop SM, Spirtos NM, Friedman RL, Lin WC, Pisani AL, Perticucci S. Relative influences of tumor volume before surgery and the cytoreductive outcome on survival for patients with advanced ovarian cancer: a prospective study. Gynecol Oncol. 2003;90:390-396.

3. Ozols RF. Systemic therapy for ovarian cancer: current status and new treatments. Semin Oncol. 2006;33(2 Suppl 6):S3-S11.

4. Salzberg M, Thurlimann B, Bonnefois H, et al. Current concepts of treatment strategies in advanced or recurrent ovarian cancer. Oncology. 2005;68:293-298.

5. Armstrong DK. Relapsed ovarian cancer: challenges and management strategies for a chronic disease. Oncologist. 2002;7 Suppl 5:20-28.

6. Colombo N, Gore M. Treatment of recurrent ovarian cancer relapsing 6-12 months post platinum-based chemotherapy. Crit Rev Oncol Haematol. 2007;64:129-138.

7. U.S. Food and Drug Administration, Center for Drug Evaluation and Research [updated 2008 Oct 06]. http://www.accessdata.fda.gov/ drugsatfda_docs/label/2008/050718s033lbl.pdf. Accessed Dec 17, 2009.

8. Gabizon A, Shmeeda H, Barenholz Y. Pharmacokinetics of pegylated liposomal Doxorubicin: review of animal and human studies. Clin Pharmacokinet. 2003;42:419-436.

9. Gabizon A, Catane R, Uziely B, et al. Prolonged circulation time and enhanced accumulation in malignant exudates of doxorubicin encapsulated in polyethylene-glycol coated liposomes. Cancer Res. 1994;54: 987-992.

10. Gabizon A, Isacson R, Rosengarten O, Tzemach D, Shmeeda H, Sapir R. An open-label study to evaluate dose and cycle dependence of the pharmacokinetics of pegylated liposomal doxorubicin. Cancer Chemother Pharmacol. 2008;4:695-702.

11. Yokoe J, Sakuragi S, Yamamoto K, et al. Albumin-conjugated PEG liposome enhances tumor distribution of liposomal doxorubicin in rats. Int J Pharm. 2008;353:28-34.

12. Bogner JR, Kronawitter U, Rolinski B, Truebenbach K, Goebel FD. Liposomal doxorubicin in the treatment of advanced AIDS-related Kaposi sarcoma. J Acquir Immune Defic Syndr. 1994;7:463-468.

13. James ND, Coker RJ, Tomlinson D, et al. Liposomal doxorubicin (Doxil): an effective new treatment for Kaposi's sarcoma in AIDS. Clin Oncol (R Coll Radiol). 1994;6:294-296.

14. Uziely B, Jeffers $S$, Isacson R, et al. Liposomal doxorubicin: antitumor activity and unique toxicities during two complementary phase I studies. J Clin Oncol. 1995;13:1777-1785.

15. Jahanzeb M, Vogel C, Elkrish M, et al. Stealth liposomal doxorubicin (Doxil) causes a mild and delayed leukopenia compared to doxorubicin in patients with solid tumors. Proc Am Soc Clin Oncol. 1997; 16:239Abstr 843.

16. Gabizon A, Uziely B, Lotem M, et al. Doxil in patients with pretreated metastatic breast cancer (MBC): a dose-schedule finding study with pharmacokinetics. Proc Am Soc Clin Oncol. 1997; 16:147 Abstr 516.

17. Caponigro F, Comella P, Budillon A, et al. Phase I study of Caelyx (doxorubicin HCL, pegylated liposomal) in recurrent or metastatic head and neck cancer. Ann Oncol. 2000;11:339-342.

18. Hamilton A, Biganzoli L, Coleman R, et al. EORTC 10968: a phase I clinical and pharmacokinetic study of polyethylene glycol liposomal doxorubicin (Caelyx, Doxil) at a 6-week interval in patients with metastatic breast cancer. European Organization for Research and Treatment of Cancer. Ann Oncol. 2002;13:910-918.

19. Marina NM, Cochrane D, Harney E, et al. Dose escalation and pharmacokinetics of pegylated liposomal doxorubicin (Doxil) in children with solid tumors: a pediatric oncology group study. Clin Cancer Res. 2002;8:413-418.

20. Harrison LE, Bryan M, Pliner L, Saunders T. Phase I trial of pegylated liposomal doxorubicin with hyperthermic intraperitoneal chemotherapy in patients undergoing cytoreduction for advanced intra-abdominal malignancy. Ann Surg Oncol. 2008;15:1407-1413.
21. Klein P, Wasserheit C, Hochster H. et al. Apparent protection of doxil skin and oral toxicities when combined with cisplatin (CDDP): results of a Phase I study. Proc Am Soc Clin Oncol. 1999;18:217 Abstr 835.

22. Lyass O, Hubert A, Gabizon AA. Phase I study of doxil-cisplatin combination chemotherapy in patients with advanced malignancies. Clin Cancer Res. 2001;7:3040-3046.

23. Uys A, Rapoport BL, Mahomed R. Phase I trial of pegylated-liposomal doxorubicin (Caelyx, Doxil) and carboplatin in patients with advanced malignancy. Proc Am Soc Clin Oncol. 2002;21:Abstr 2138.

24. Goncalves A, Braud AC, Viret F, et al. Phase I study of pegylated liposomal doxorubicin (Caelyx) in combination with carboplatin in patients with advanced solid tumors. Anticancer Res. 2003;23: 3543-3548.

25. Hamilton AL, Pavlick AC, Volm M, et al. Pegylated liposomal doxorubicin (PLD) and carboplatin: a Phase I study of combination therapy with maintenance PLD. Proc Am Soc Clin Oncol. 2003;22:Abstr 1986.

26. Gonzalez-Billalabeitia E, Mendiola C, Mellado B, et al. for the Grupo PSAMOMA; A phase I/II clinical study of pegylated liposomal doxorubicin plus carboplatin in advanced ovarian cancer. Proc Am Soc Clin Oncol. 2003;22:Abstr 1919.

27. du Bois A, Burges A, Meier W, et al. Arbeitsgemeinschaft Gynaekologische Onkologie Studiengruppe Ovarialkarzinom. Pegylated liposomal doxorubicin and carboplatin in advanced gynecologic tumors: a prospective phase I/II study of the Arbeitsgemeinschaft Gynaekologische Onkologie Studiengruppe Ovarialkarzinom (AGO-OVAR). Ann Oncol. 2006;17:93-96.

28. Recchia F, Saggio G, Amiconi G, et al. A multicenter phase II study of pegylated liposomal doxorubicin and oxaliplatin in recurrent ovarian cancer. Gynecol Oncol. 2007;106:164-169.

29. Israel VK, Jeffers S, Bernal G, et al. Phase I study of doxil (liposomal doxorubicin) in combination with paclitaxel. Proc Am Soc Clin Oncol. 1998:Abstr 938.

30. Muggia FM, Hornreich G, Wadler S, et al. Overview of toxicities from a combination of Doxil-paclitaxel (PachiDox) in a New York Gynecologic Oncology Group (NYGOG) study on endometrial carcinomas and sarcomas. Proc Am Soc Clin Oncol. 2000:Abstr 1616.

31. Modiano M, Taylor C, Sharpington T, Ng M, Martinez A. Phase I study of Doxil (pegylated liposomal doxorubicin) plus escalating doses of Taxol in the treatment of patients with advanced breast or gynecologic malignancies. Proc Am Soc Clin Oncol. 1999:Abstr 848.

32. Schwonzen M, Kurbacher CM, Mallmann P. Liposomal doxorubicin and weekly paclitaxel in the treatment of metastatic breast cancer. Anticancer Drugs. 2000;11:681-685.

33. Tolis C, Briasoulis E, Tzamakou E, et al. Phase I trial and interaction pharmacokinetics of pegylated-liposomal doxorubicin (Caelyx; Doxil) and weekly Taxol. Proc Am Soc Clin Oncol. 2000;19:Abstr 803.

34. Androulakis N, Kouroussis C, Mavroudis D, et al. Phase I study of weekly paclitaxel and liposomal doxorubicin in patients with advanced solid tumours. Eur J Cancer. 2002;38:1992-1997.

35. Mavroudis D, Kouroussis C, Kakolyris S, et al. Phase I study of paclitaxel (taxol) and pegylated liposomal doxorubicin (caelyx) administered every 2 weeks in patients with advanced solid tumors. Oncology. 2002;62:216-222.

36. Lortholary A, Delozier T, Bourgeois H, et al. A phase I study of paclitaxel in combination with pegylated liposomal doxorubicin (PLD) as second-line chemotherapy in metastatic breast cancer (MBC). Proc Am Soc Clin Oncol. 2003;22:Abstr 206.

37. Briasoulis E, Pentheroudakis G, Karavasilis V, et al. Weekly paclitaxel combined with pegylated liposomal doxorubicin (CaelyxTM) given every 4 weeks: dose-finding and pharmacokinetic study in patients with advanced solid tumors. Ann Oncol. 2004;15:1566-1573.

38. Hirsch R, Jahanzeb M. Phase I Study of Doxil in Combination with Escalating Doses of Taxotere in the Treatment of Patients with Advanced Malignancies (Meeting abstract). Proc Am Soc Clin Oncol. 1999: Abstr 820. 
39. Drinkard L, Blumenschein G, DiStefano A, Adams J. A Phase I trial of liposomal doxorubicin (Doxil) given on day one followed by docetaxel (Taxotere) given on day five in patients with advanced solid tumors. (Meeting abstracts). Proc Am Soc Clin Oncol. 1999;18:Abstr 801.

40. Pavlick AC, Chodkiewicz C, Liebes L, et al. A phase I and pharmacokinetic study of docetaxel combined with Doxil (pegylated liposomal doxorubicin) without and with granulocyte colony stimulating factor. Anticancer Drugs. 2004;15:119-125.

41. Tauer K, Hussein A, Birch R, et al. A phase i study of Taxotere (T) and Doxil (D) in refractory cancer. Proc Am Soc Clin Oncol. 2000;19: Abstr 901.

42. Sparano JA, Malik U, Rajdev L, et al. Phase I trial of pegylated iposomal doxorubicin and docetaxel in advanced breast cancer. J Clin Oncol. 2001;15;19:3117-3125.

43. Sikov WM, Hsieh M, Lopez F. Phase I weekly docetaxel with doxorubicin or Doxil: a BrUOG study. Proc Am Soc Clin Oncol. 2001;20: Abstr 2088

44. Gasparini G, Morabito A, Fanelli M, et al. Phase I-II study of liposomal doxorubicin and docetaxel as first-line treatment in patients with advanced breast cancer. Proc Am Soc Clin Oncol. 2002;21:Abstr 2029.

45. Fracasso PM, Rodriguez LC, Herzog TJ, et al. Phase I dose and sequencing study of pegylated liposomal doxorubicin and docetaxel in patients with advanced malignancies. Cancer. 2003;98:610-617.

46. Bischoff J, Hesse S, Stemmler H, Zauner S, Gutschow K. A phase I study of PEG liposomal doxorubicin (PLD) plus docetaxel (D) in metastatic breast cancer (MBC). Proc Am Soc Clin Oncol. 2003;22 Abstr 282.

47. Eng C, Mauer AM, Fleming GF, et al. MJ. Phase I study of pegylated liposomal doxorubicin, paclitaxel, and cisplatin in patients with advanced solid tumors. Ann Oncol. 2001;12:1743-1747.

48. Rose PG, Greer BE, Horowitz IR, Markman M, Fusco N. Paclitaxel, carboplatin, and pegylated liposomal doxorubicin in ovarian, and peritoneal carcinoma: A phase I study of the Gynecologic Oncology Group. Gynecol Oncol. 2007;104: 114-119.

49. Gibbs DD, Pyle L, Allen M, et al. A phase I dose-finding study of a combination of Pegylated liposomal doxorubicin (Doxil), carboplatin and paclitaxel in ovarian cancer. Br J Cancer. 2002;86: 1379-1384.

50. Ryan CW, Fleming GF, Janisch L, et al. A phase I study of liposomal doxorubicin (Doxil) with topotecan. Am J Clin Oncol. 2000;23: 297-300.

51. Yeung AW, Wong A, Ali M. Phase I trial of doxil and topotecan in solid tumors. Proc Am Soc Clin Oncol. 1998:Abstr 979.

52. Hochster H, Rosenthal M, Chachoua M, Sorich J, Muggia F. Prolonged topotecan infusion combined with doxil. a well tolerated regimen. Proc Am Soc Clin Oncol. 1999;18:214:Abstr 822.

53. Hamilton A, Hoechster H, Rosenthal M, et al. Continuous infusion topotecan (TP-CI) with Doxil (DX): a phase I study of dual topoisomerase inhibition. Proc Am Soc Clin Oncol. 2000;19:Abstr 777.

54. Geertsen PF, Strøyer I, Herrstedt J, Werner Hansen S. Phase I study of topotecan (T) and pegylated liposomal doxorubicin (Caelyx) in patients (pts) with progressive ovarian cancer within 12 months after first-line platinum-paclitaxel containing chemotherapy. Proc Am Soc Clin Oncol. 2001;20:Abstr 2522.

55. Pautier P, Germann N, Faivre S, et al. Phase I study of Caelyx (KLX stealth stabilized liposomal doxorubicin - Doxil) in combination with topotecan (TPT). Proc Am Soc Clin Oncol. 2000;19:Abstr 910.

56. Mirchandani D, Hochster H, Hamilton A, et al. Phase I study of combined pegylated liposomal doxorubicin with protracted daily topotecan for ovarian cancer. Clin Cancer Res. 2005;11:5912-5919.

57. Garcia AA, Roman L, Muderspach L, et al. Phase I clinical trial of topotecan and pegylated liposomal doxorubicin. Cancer Invest. 2005;23:665-670.

58. Ghesquieres H, Faivre S, Djafari L, et al. Phase I dose escalation study of pegylated liposomal doxorubicin (Caelyx) in combination with topotecan in patients with advanced malignancies. Invest New Drugs. 2006;24:413-421.
59. Rose PG, Smrekar M, Haba P, Fusco N, Rodriguez M. A phase I study of oral topotecan and pegylated liposomal doxorubicin (doxil) in platinum-resistant ovarian and peritoneal cancer. Am J Clin Oncol. 2008;31:476-480.

60. Penson RT, Seiden MV, Goodman A, et al. Gynecologic Oncology Research Program at Dana Farber/Partners CancerCare. Phase I trial of escalating doses of topotecan in combination with a fixed dose of pegylated liposomal doxorubicin in women with müllerian malignancies. Gynecol Oncol. 2004;93(3):702-707.

61. Laufman LR, Spiridonidis CH, Jones JJ, Rhodes V, Rossi K, Wallace K. Phase I study of Doxil and vinorelbine in patients with advanced malignancies. Cancer Invest. 2004;22:344-352.

62. D'Agostino G, Ferrandina G, Garganese G, et al. Phase I study of gemcitabine and liposomal doxorubicin in relapsed ovarian cancer. Oncology. 2002;62:110-114.

63. Fracasso PM, Blum KA, Tan BR, et al. Phase I study of pegylated liposomal doxorubicin and gemcitabine in patients with advanced malignancies. Cancer. 2002;95:2223-2229.

64. Bozionelou V, Vamvakas L, Pappas P, et al. A dose escalation and pharmacokinetic study of biweekly pegylated liposomal doxorubicin, paclitaxel and gemcitabine in patients with advanced solid tumours. Br J Cancer. 2007;97:43-49.

65. Muggia FM, Hainsworth JD, Jeffers S, et al. Phase II study of liposomal doxorubicin in refractory ovarian cancer: antitumor activity and toxicity modification by liposomal encapsulation. J Clin Oncol. 1997; 15:987-993

66. Gordon AN, Granai CO, Rose PG, et al. Phase II study of liposomal doxorubicin in platinum- and paclitaxel-refractory epithelial ovarian cancer. J Clin Oncol. 2000;18:3093-3100.

67. Rose PG, Maxson JH, Fusco N, et al. Liposomal doxorubicin in ovarian, peritoneal, and tubal carcinoma: a retrospective comparative study of single-agent dosages. Gynecol Oncol. 2001;82:323-328.

68. Arcuri C, Sorio R, Tognon G, et al. A phase II study of liposomal doxorubicin in recurrent epithelial ovarian carcinoma. Tumori. 2006; 90:556-561.

69. Katsumata N, Fujiwara Y, Kamura T, et al. Phase II clinical trial of pegylated liposomal doxorubicin (JNS002) in Japanese patients with mullerian carcinoma (epithelial ovarian carcinoma, primary carcinoma of fallopian tube, peritoneal carcinoma) having a therapeutic history of platinum-based chemotherapy: a Phase II Study of the Japanese Gynecologic Oncology Group. Jpn J Clin Oncol. 2008;38: 777-785

70. Gorumlu G, Kucukzeybek Y, Kemal-Gul M, et al. Pegylated liposomal doxorubicin in heavily pretreated epithelial ovarian cancer patients. J BUON. 2008;13(3):349-352.

71. Steppan I, Reimer D, Sevelda U, Ulmer H, Marth C, Zeimet AG. Treatment of recurrent platinum-resistant ovarian cancer with pegylated liposomal doxorubicin-an evaluation of the therapeutic index with special emphasis on cardiac toxicity. Chemotherapy. 2009;55:391-398.

72. Chou HH, Wang KL, Chen CA, et al. 2005. Pegylated liposomal doxorubicin (Lipo-Dox $(\mathrm{R})$ ) for platinum-resistant or refractory epithelial ovarian carcinoma: A Taiwanese gynecologic oncology group study with long term follow-up. Gynecol Oncol. 2006;101:423-428.

73. Markman M, Kennedy A, Webster K, et al. Phase 2 trial of liposomal doxorubicin $\left(40 \mathrm{mg} / \mathrm{m}^{2}\right)$ in platinum/paclitaxel-refractory ovarian and fallopian tube cancers and primary carcinoma of the peritoneum. Gynecol Oncol. 2000;78:369-72.

74. Campos SM, Penson RT, Mays AR, et al. The clinical utility of liposomal doxorubicin in recurrent ovarian cancer. Gynecol Oncol. 2001;81:206-212.

75. Wilailak S, Linasmita V. A study of pegylated liposomal Doxorubicin in platinum-refractory epithelial ovarian cancer. Oncology. 2004;67:183-186.

76. Lorusso D, Naldini A, Testa A, et al. Phase II study of pegylated liposomal doxorubicin in heavily pretreated epithelial ovarian cancer patients. May a new treatment schedule improve toxicity profile? Oncology. 2004;67:243-239. 
77. Strauss HG, Hemsen A, Karbe I, Lautenschläger C, Persing M, Thomssen C. Phase II trial of biweekly pegylated liposomal doxorubicin in recurrent platinum-refractory ovarian and peritoneal cancer. Anticancer Drugs. 2008;19:541-545.

78. Oskay-Oezcelik G, Koensgen D, Hindenburg HJ, et al. Biweekly pegylated liposomal doxorubicin as second-line treatment in patients with relapsed ovarian cancer after failure of platinum and paclitaxel: results from a multi-center phase II study of the NOGGO. Anticancer Res. 2008;28:1329-1334.

79. Sehouli J, Oskay-Ozcelik G, Kühne J, et al. Biweekly pegylated liposomal doxorubicin in patients with relapsed ovarian cancer: results of a multicenter phase-II trial. Ann Oncol. 2006;17:957-961.

80. Sehouli J, Camara O, Schmidt M, et al. North-Eastern German Society of Gynecological Oncology. Pegylated liposomal doxorubicin (CAELYX) in patients with advanced ovarian cancer: results of a German multicenter observational study. Cancer Chemother Pharmacol. 2009;64:585-591.

81. Parmar MK, Ledermann JA, Colombo N, et al. ICON and AGO Collaborators. Paclitaxel plus platinum-based chemotherapy versus conventional platinum-based chemotherapy in women with relapsed ovarian cancer:the ICON4/AGO-OVAR-2.2 trial. Lancet. 2003;361:2099-2106.

82. Pfisterer J, Plante M, Vergote I, et al. AGO-OVAR; NCIC CTG; EORTC GCG. Gemcitabine plus carboplatin compared with carboplatin in patients with platinum-sensitive recurrent ovarian cancer: an intergroup trial of the AGO-OVAR, the NCIC CTG, and the EORTC GCG. J Clin Oncol. 2006;24:4699-4707.

83. Tas F, Derin D, Guney N, Aydiner A, Topuz E. Chemotherapy with pegylated liposomal doxorubicin and cisplatin in recurrent platinumsensitive epithelial ovarian cancer. Int J Clin Oncol. 2008;13: 330-334.

84. Vorobiof DA, Rapoport BL, Slabber CF, et al. Phase 2 study of combination therapy with liposomal doxorubicin and carboplatin in patients with relapsed, platinum sensitive ovarian cancer. Proc Am Soc Clin Oncol. 2004;23:471s.

85. du Bois A, Pfisterer J, Burchardi N, et al. Arbeitsgemeinschaft Gynäekologische Onkologie Studiengruppe Ovarialkarzinom; Kommission Uterus. Combination therapy with pegylated liposomal doxorubicin and carboplatin in gynecologic malignancies: a prospective phase II study of the Arbeitsgemeinschaft Gynäekologische Onkologie Studiengruppe Ovarialkarzinom (AGO-OVAR) and Kommission Uterus (AGO-K-Ut). Gynecol Oncol. 2007;107:518-525.

86. Rapoport BL, Vorobiof DA, Slabber C, et al. Phase II study of pegylated liposomal doxorubicin and carboplatin in patients with platinumsensitive and partially platinum-sensitive metastatic ovarian cancer. Int J Gynecol Cancer. 2009;19:1137-1141.

87. Ferrero JM, Weber B, Geay JF, et al. Second-line chemotherapy with pegylated liposomal doxorubicin and carboplatin is highly effective in patients with advanced ovarian cancer in late relapse: a GINECO phase II trial. Ann Oncol. 2007;18:263-268.

88. Power P, Stuart G, Oza A, et al. Efficacy of pegylated liposomal doxorubicin (PLD) plus carboplatino in ovarian cancer patients who recur within six to twelve months: a phase II study. Gynecol Oncol. 2009; 114:410-414.

89. Weber B, Lortholary A, Mayer F, et al. Pegylated liposomal doxorubicin and carboplatin in late-relapsing ovarian cancer: a GINECO group phase II trial. Anticancer Res. 2009;29:4195-4200.

90. Nicoletto MO, Falci C, Pianalto D, et al. Phase II study of pegylated liposomal doxorubicin and oxaliplatin in relapsed advanced ovarian cancer. Gynecol Oncol. 2006;100:318-323.

91. Recchia F, De Filippis S, Saggio G, et al. Phase I study of liposomal doxorubicin and oxaliplatin as salvage chemotherapy in advanced ovarian cancer. Anticancer Drugs. 2003;14:633-638.

92. Valerio MR, Tagliaferri P, Raspagliesi F, et al. A phase II study of pegylated liposomal doxorubicin oxaliplatin and cyclophosphamide as second-line treatment in relapsed ovarian carcinoma. Int $J$ Gynecol Cancer. 2006;16(Suppl 1):79-85.
93. Smith HO, Moon J, Wilczynski SP, et al. Southwest Oncology Group Trial S9912: intraperitoneal cisplatin and paclitaxel plus intravenous paclitaxel and pegylated liposomal doxorubicin as primary chemotherapy of small-volume residual stage III ovarian cancer. Gynecol Oncol. 2009;114:206-209.

94. Tas F, Guney N, Derin D, Aydiner A, Topuz E. A pilot study evaluating the efficacy and toxicity of biweekly gemcitabine and pegylated liposomal doxorubicin in recurrent platinum-resistant epithelial ovarian cancer. Int J Clin Oncol. 2008;13:156-160.

95. Skarlos DV, Kalofonos HP, Fountzilas G, et al. Gemcitabine plus pegylated liposomal doxorubicin in patients with advanced epithelial ovarian cancer resistant/refractory to platinum and/or taxanes. A HeCOG phase II study. Anticancer Res. 2005;25:3103-3108.

96. Holloway RW, Finkler NJ, Nye LP, et al. Doxil and gemcitabine combination therapy for recurrent ovarian cancer: results of a phase II trial. Proc Am Soc Clin Oncol. 2004;Abstr 5090.

97. Karaoglu A, Arslan UY, Ozkan M, et al. Efficacy and toxicity of gemcitabine and pegylated liposomal Doxorubicin in recurrent platinum-resistant/refractory epithelial ovarian cancer. Asian Pac $J$ Cancer Prev. 2009;10:63-66.

98. Petru E, Angleitner-Boubenizek L, Reinthaller A, et al.Combined PEG liposomal doxorubicin and gemcitabine are active and have acceptable toxicity in patients with platinum-refractory and -resistant ovarian cancer after previous platinum-taxane therapy: A phase II Austrian AGO study. Gynecol Oncol. 2006;101:18-23.

99. D'Agostino G, Ferrandina G, Ludovisi M, et al. Phase II study of liposomal doxorubicin and gemcitabine in the salvage treatment of ovarian cancer. Br J Cancer. 2003;89:1180-1184.

100. Ferrandina G, Paris I, Ludovisi M, et al. Gemcitabine and liposomal doxorubicin in the salvage treatment of ovarian cancer: updated results and long-term survival. Gynecol Oncol. 2005;98:267-273.

101. Tanyi JL, Smith JA, Ramos L, Parker CL, Munsell MF, Wolf JK. Predisposing risk factors for palmar-plantar erythrodysesthesia when using liposomal doxorubicin to treat recurrent ovarian cancer. Gynecol Oncol. 2009;114:219-224.

102. Verhaar-Langereis M, Karakus A, van Eijkeren M, et al. Phase II study of the combination of pegylated liposomal doxorubicin and topotecan in platinum-resistant ovarian cancer. Int J Gynecol Cancer. 2006; $16: 65-70$

103. Campos SM, Matulonis UA, Penson RT, et al. 2003. Phase II study of liposomal doxorubicin and weekly paclitaxel for recurrent Mullerian tumors. Gynecol Oncol. 2003;90:610-618.

104. Katsaros D, Oletti MV, Rigault de la Longrais IA, et al. Clinical and pharmacokinetic phase II study of pegylated liposomal doxorubicin and vinorelbine in heavily pretreated recurrent ovarian carcinoma. Ann Oncol. 2005;16:300-306.

105. Joly F, Sevin E, Lortholary A, et al. Association of pegylated liposomal doxorubicin and ifosfamide in early recurrent ovarian cancer patients: A multicenter phase II trial. Gynecol Oncol. 2009, Nov 2 [Epub ahead of print)

106. O’Byrne KJ, Bliss P, Graham JD, et al. A Phase III study of Doxil/ Caylex versus paclitaxel in platinum treated taxane naive relapsed ovarian cancer. Proc Am Soc Clin Oncol. 2002;21:Abstr 808).

107. Gordon AN, Fleagle JT, Guthrie D, Parkin DE, Gore ME, Lacave AJ. Recurrent epithelial ovarian carcinoma: a randomized phase III study of pegylated liposomal doxorubicin versus topotecan. J Clin Oncol. 2001;19:3312-3322.

108. Gordon AN, Tonda M, Sun S, Rackoff W. Long-term survival advantage for women treated with pegylated liposomal doxorubicin compared with topotecan in a phase 3 randomized study of recurrent and refractory epithelial ovarian cancer. Gynecol Oncol. 2004;95:1-8.

109. Mutch DG, Orlando M, Goss T, et al. Randomized phase III trial of gemcitabine compared with pegylated liposomal doxorubicin in patients with platinum-resistant ovarian cancer. J Clin Oncol. 2007;25:2811-2818.

110. Ferrandina G, Ludovisi M, Lorusso D, et al. Phase III trial of gemcitabine compared with pegylated liposomal doxorubicin in progressive or recurrent ovarian cancer. J Clin Oncol. 2008;26:890-896. 
111. Satyam A, Hocker MD, Kane Maguire KA, Morgan AS, Villar HO, Lyttle MH. Design, synthesis and evalution of latent alkylating agents activated by glutathione S-transferase. J Med Chem. 1996;39: $1736-1747$.

112. Vergote I, Finkler N, del Campo J, et al. Phase 3 randomised study of canfosfamide (Telcyta, TLK286) versus pegylated liposomal doxorubicin or topotecan as third-line therapy in patients with platinum-refractory or -resistant ovarian cancer. Eur J Cancer. 2009;45:2324-2332.

113. Vergote I, Finkler J, Hall JB, et al. Randomized phase III study of canfosfamide (C, TLK286) plus pegylated liposomal doxorubicin (PLD) versus PLD as second-line therapy in platinum $(\mathrm{P})$ refractory or resistant ovarian cancer (OC). Proc Am Soc Clin Oncol. 2009:Abstr 5552.

114. Ganjoo KN, Patel SR. Trabectedin: an anticancer drug from the sea. Exp Opin Pharmacother. 2009;10:2735-2743.

115. von Mehren M, Schilder RJ, Cheng JD, et al. A phase I study of the safety and pharmacokinetics of trabectedin in combination with pegylated liposomal doxorubicin in patients with advanced malignancies. Ann Oncol. 2008;19:1802-1809.

116. McMeekin S, Del Campo JM, Colombo N, et al. Trabectedin (T) in relapsed advanced ovarian cancer (ROC): a pooled analysis of three phase II studies. Proc Am Soc Clin Oncol. 2007;25:18sAbstr 5579 .

117. Monk BJ, Herzog T, Kaye S, et al. A randomized Phase III study of trabectedin with pegylated liposomal doxorubicin (PLD) versus PLD in relapsed ovarian cancer (OC). 2008; Proceedings of ESMO; Ann Oncol. 19:9Abstr LBA4.

118. Krasner CN, Poveda A, Herzog T, et al. Health-related quality of life/patient-reported outcomes in relapsed ovarian cancer: results from a randomized phase III study of trabectedin with pegylated liposomal doxorubicin (PLD) versus PLD alone. Proc Am Soc Clin Oncol. 2009;27:15sAbstr 5526.

119. Alberts DS, Liu PY, Wilczynski SP, et al. Randomized trial of pegylated liposomal doxorubicin (PLD) plus carboplatin in platinum sensitive (PS) patients with recurrent epithelial ovarian or peritoenal carcinoma after failure of initial platinum-based chemotherapy (Southwest Oncology Group Protocol S0200). Gynecol Oncol. 2008;108: 90-94.

120. Markman M, Moon J, Wilczynski S, et al. Single agent carboplatin versus carboplatin plus pegylated liposomal doxorubicin in recurrent ovarian cancer: Final survival results of a SWOG (S0200) phase 3 randomized trial. Gynecol Oncol. 2009 Dec 29. [Epub ahead of print].

121. Linardou H, Bafaloukos D, Bamlas A, et al. A randomized, Phase II study of carboplatin plus liposomal doxorubicin (CLD) vs carboplatin plus paclitaxel (CP) in potentially platinum sensitive ovarian cancer patients. A Hellenic Cooperative Oncology Group. Eur J Cancer. 2007;5(Suppl):3122Abstr 5003.

122. Pujade-Lauraine E, Mahner S, Kaern J, et al. A randomized, phase III study of carboplatin and pegylated liposomal doxorubicin versus carboplatin and paclitaxel in relapsed platinum-sensitive ovarian cancer (OC): CALYPSO study of the Gynecologic Cancer Intergroup (GCIG). J Clin Oncol. 2009;27(18s) suppl:Abstr LBA5509.

123. Vasey P, Largillier R, Gropp M, et al. A GCIC randomized phase III study of carboplatin (C) and pegylated liposomal doxorubicin (PLD) (C-D) vs carboplatin and paclitaxel (P) (C-P): CALYPSO results in partially platinum-sensitive ovarian cancer $(\mathrm{OC})$. Proc ESMO 2009:Abstr LBA18.

124. Potamianou A, Androulakis N, Papakotoulas P, et al. Sequential combination of paclitaxel-carboplatin and paclitaxel-liposomal doxorubicin as a first-line treatment in patients with ovarian cancer. A multicenter phase II trial. Oncology. 2005;69:348-353.

125. Bookman MA, Brady MF, McGuire WP, et al. Evaluation of new platinum-based treatment regimens in advanced-stage ovarian cancer: a Phase III Trial of the Gynecologic Cancer Intergroup. J Clin Oncol. 2009;20;27:1419-1425.
126. Pignata S, Scambia G, Savarese A, et al; MITO Investigators. Safety of a 3-weekly schedule of carboplatin plus pegylated liposomal doxorubicin as first line chemotherapy in patients with ovarian cancer: preliminary results of the MITO-2 randomized trial. BMC Cancer. 2006;6:202.

127. Pignata S, Scambia G, Savarese A, et al. Carboplatin and pegylated liposomal doxorubicin for advanced ovarian cancer: preliminary activity results of the MITO-2 phase III trial. Oncology. 2009;76: 49-54.

128. Pignata S, Scambia G, Savarese A, et al. Carboplatin plus paclitaxel (CP) versus carboplatin plus stealth liposomal doxorubicin (CLD) in patients with advanced ovarian cancer: activity and safety results of the MITO-2 randomised multicenter trials. Proc Am Soc Clin Oncol. 2009;27:LBA 5508.

129. Sánchez-Muñoz A, Pérez-Ruiz E, Mendiola Fernández C, Alba Conejo E, González-Martín A. Current status of anti-angiogenic agents in the treatment of ovarian carcinoma. Clin Transl Oncol. 2009;11:589-595.

130. Muggia FM, Boyd L, Liebes L, et al. Pegylated liposomal doxorubicin (PLD) with bevacizumab (B) in second-line treatment of ovarian cancer (OC): pharmacokinetics (PK), safety, and preliminary outcome results. Proc Am Soc Clin Oncol. 2009:Abstr 5548.

131. Kikuchi Y, Kouta H, Kikuchi, et al. Effects of weekly bevacizumab and pegylated liposomal doxorubicin in heavily pretreated patients with recurrent or progressed ovarian cancer. Proc Am Soc Clin Oncol. 2009:Abstr 5547.

132. Ramakrishnan V, Bhaskar V, Law DA, et al. Preclinical evaluation of an anti alpha5beta1 integrin antibody as a novel antingiogenic agent. $J$ Exp Ther Oncol. 2006;5:273-286.

133. Vergote I, Colombo N, Kutarska E, et al. Phase II study comparing volociximab (an antiangiogenic antibody) and pegylated liposomal doxorubicin (PLD) with PLD alone in recurrent ovarian or primary peritoneal cancer. Proc Am Soc Clin Oncol. 2009:Abstr 5560.

134. Dees EC, O’Neil BH, Lindley CM, et al. Phase I and pharmacologic study of the combination of bortezomib and pegylated liposomal doxorubicin in patients with refractory solid tumors. Cancer Chemother Pharmacol. 2008;63:99-107.

135. Scambia G, Parma G, Del Conte D, et al. A phase II combination study of bortezomib with pegylated-liposomal doxorubicin in patients with ovarian cancer failing platinum containing regimens. Proc Am Soc Clin Oncol. 2008:Abstr 5581.

136. O'Brien ME, Wigler N, Inbar M, et al. Reduced cardiotoxicity and comparable efficacy in a phase III trial of pegylated liposomal doxorubicin $\mathrm{HCl}$ (CAELYX/Doxil) versus conventional doxorubicin for first-line treatment of metastatic breast cancer. Ann Oncol. 2004;15:440-449.

137. Martschick A, Sehouli J, Patzelt A, et al. Pathogenetic mechanism of anthracycline-induced palmar-plantar erythrodysesthesia. Anticancer Res. 2009;29:2307-2313.

138. Jacobi U, Waibler E, Schulze P, et al. Release of doxorubicin in sweat: first step to induce the palmar-plantar erythrodysesthesia syndrome? Ann Oncol. 2005;16:1210-1211.

139. Gordinier ME, Dizon DS, Fleming EL, et al. Elevated body mass index does not increase the risk of palmar-plantar erythrodysesthesia in patients receiving pegylated liposomal doxorubicin. Gynecol Oncol. 2006;103:72-74.

140. Lyass O, Uziely B, Ben-Yosef R, et al. Correlation of toxicity with pharmacokinetics of pegylated liposomal doxorubicin (Doxil) in metastatic breast carcinoma. Cancer. 2000;89:1037-1047.

141. Molpus KL, Anderson LB, Craig CL, Puleo JG. The effect of regional cooling on toxicity associated with intravenous infusion of pegylated liposomal doxorubicin in recurrent ovarian carcinoma. Gynecol Oncol. 2004;93:513-516.

142. Lorusso D, Di Stefano A, Carone V, Fagotti A, Pisconti S, Scambia G. Pegylated liposomal doxorubicin-related palmar-plantar erythrodysesthesia ('hand-foot' syndrome). Ann Oncol. 2007;18: $1159-1164$. 
143. Von Gruenigen VE, Frasure H, Fusco N, et al. A double-blind ranodmized trial of pyridoxine versus placebo fort he prevention of pegylated liposomal doxorubicin hydrochloride-related palamr-plantar erythrodysesthesia. Proc Am Soc Clin Oncol. 2009:Abstr 5594.

144. Coleman RE, Biganzoli L, Canney P, et al. A randomised phase II study of two different schedules of pegylated liposomal doxorubicin in metastatic breast cancer (EORTC-10993). Eur J Cancer. 2006;42:882-887.
145. von Moos R, Thuerlimann BJ, Aapro M, et al. Pegylated liposomal doxorubicin-associated hand-foot syndrome: recommendations of an international panel of experts. Eur J Cancer. 2008;44:781-790.

Therapeutics and Clinical Risk Management

\section{Publish your work in this journal}

Therapeutics and Clinical Risk Management is an international, peerreviewed journal of clinical therapeutics and risk management, focusing on concise rapid reporting of clinical studies in all therapeutic areas, outcomes, safety, and programs for the effective, safe, and sustained use of medicines. This journal is indexed on PubMed Central, CAS,
EMBase, Scopus and the Elsevier Bibliographic databases. The manuscript management system is completely online and includes a very quick and fair peer-review system, which is all easy to use. Visit http://www.dovepress.com/testimonials.php to read real quotes from published authors.

Submit your manuscript here: http://www.dovepress.com/therapeutics-and-clinical-risk-management-journal 